Caracterização do clima urbano em Teodoro Sampaio/SP: Uma introdução Simone Scatolon Menotti Viana, Margarete Cristiane de Costa Trindade Amorim

\title{
CARACTERIZAÇÃO DO CLIMA URBANO EM TEODORO SAMPAIO/SP: UMA INTRODUÇÃO
}

\section{Urban climate characterization at Teodoro Sampaio/SP, Brazil: an introduction}

\author{
Simone Scatolon Menotti Viana \\ Mestre em Geografia pela Faculdade de Ciências e Tecnologia da \\ Universidade Estadual Paulista - UNESP - Presidente Prudente/SP \\ simoneviana10@yahoo.com.br
}

Margarete Cristiane de Costa Trindade Amorim Professora Doutora do Programa de Pós-Graduação e de Graduação em Geografia da Faculdade de Ciências e Tecnologia - UNESP - Presidente Prudente/SP mccta@fct.unesp.br

Artigo recebido para publicação em 29/07/07 e aceito para publicação em 10/03/08

RESUMO: $\quad$ Este estudo teve como objetivo principal investigar as características da temperatura e umidade relativa do ar intra-urbana e da zona rural próxima a Teodoro Sampaio, SP, cidade de pequeno porte que está localizada a 22 53' 25" S e 52 16' 75" W, no extremo Oeste do Estado de São Paulo/Brasil. Para a coleta de dados foram utilizados miniabrigos meteorológicos. Os miniabrigos meteorológicos foram equipados com psicrômetros e distribuidos em sete pontos, sendo seis na área urbana e um na área rural, sendo que as coletas de dados foram realizadas às $7 \mathrm{~h}, 9 \mathrm{~h}, 15 \mathrm{~h}$ e $21 \mathrm{~h}$. As coletas de dados aconteceram em dias representativos de janeiro de 2005 - verão; e em julho de 2005 - inverno. Esse estudo concluiu que Teodoro Sampaio, cidade de pequeno porte com aproximadamente 16.000 habitantes, já possui um clima urbano específico, conseqüência da ocupação do solo e das funcionalidades urbanas, o que acabou gerando para a cidade ilhas de calor e de frescor.

Palavras chave: Clima urbano, ilhas de calor, ilhas de frescor, Teodoro Sampaio.

ABSTRACT: The aim of this study was to investigate the temperature and the relative humidity characteristics from the intra-urban and rural areas around Teodoro Sampaio, SP, a small town located at $22^{\circ} 53^{\prime} 25^{\prime \prime} S$ and $52^{\circ} 16^{\prime} 75^{\prime \prime} \mathrm{W}$, in the most western part of the Sao Paulo state, Brazil. Small meteorological shelters were used to collect data. These shelters were supplied with psychrometers and distributed over seven locals, six in the urban area and one in the rural area, and data collection were made at $7 \mathrm{~h}, 9 \mathrm{~h}, 15 \mathrm{~h}$ e 21 h, during some typical days of January 2005 (summer) and July 2005 (winter). It was concluded that Teodoro Sampaio, a sixteen thousand inhabitants small town, has already a specific urban climate as a result of the land occupation and urban functionalities which created heat and coolness islands in the town.

Keywords: Urban climate, heat islands, coolness islands, Teodoro Sampaio. 


\section{INTRODUÇÃO}

As primeiras preocupações com o clima urbano surgiram antes da Revolução Industrial no Ocidente.

Nos últimos séculos, principalmente depois da $2^{\text {a }}$ Guerra Mundial, tem se verificado um modelo de civilização que impõe-se ao meio natural. Esse modelo de civilização tem como base de sustentação a industrialização e a urbanização. A industrialização como a responsável pela organização das formas de produção e do trabalho e a urbanização como um processo de concentração populacional nas cidades.

De acordo com Santos (1991), o desenvolver do processo de urbanização gera para o ambiente repercussões importantíssimas, como a criação de um "meio geográfico artificial" para cada local especificamente, no qual se desenvolve de maneira imprópria a vida e as condições ambientais.

Nesse sentido as cidades podem ser entendidas como organizações excelentemente humanas, nas quais o homem atua com toda a sua plenitude, transformando a natureza em prol de suas necessidades. Assim, o Homem elegeu a cidade como sua morada e a cada ano que passa o número de pessoas nas cidades vem crescendo (SANTOS, 1991).

Associadas ao crescimento populacional intenso encontram-se taxas elevadas de exclusão social e falta de investimentos, o que faz gerar um número cada vez maior de excluídos que vivem em condições de miséria nas cidades. Como resultado, tem-se um agravamento dos problemas sociais, como também, dos problemas ambientais urbanos.

Em busca de melhorar esse meio ambiente já deteriorado, o homem vem criando ambientes cada vez mais artificiais para suprir as suas necessidades. Dessa forma, na busca de construir, ou melhor, edificar um ambiente para si, o homem modifica o equilíbrio entre a superfície e a atmosfera. Uma modificação que pode ser citada é a relacionada às mudanças na temperatura e na umidade intra-urbana e rural. Assim, surge a necessidade de estudos que privilegiem a análise do comportamento da atmosfera urbana.

O clima urbano é específico para cada ambiente urbanizado, e este consiste na modificação dos elementos climáticos, como a temperatura, a umidade relativa e a direção dos ventos. Para Monteiro (1990a), o clima urbano pode ser entendido como um sistema complexo, aberto, adaptativo que, ao receber energia do ambiente maior no qual se insere, transforma-o substancialmente, a ponto de gerar uma produção exportada ao ambiente.

Os estudos sobre clima urbano realizados até o momento têm dado maior relevância a cidades de grande porte, supostamente pelo maior comprometimento da qualidade de vida e pelo agravamento dos problemas ambientais. No Brasil, há alguns trabalhos realizados em cidades de pequeno e de médio portes, embora, em nível internacional, exista maior número de trabalhos relacionados à investigação de clima urbano em cidades de pequeno porte.

Considerando-se a carência de estudos sobre a qualidade do ambiente urbano de pequeno porte no Brasil, e a necessidade de se realizar pesquisas que se referem à qualidade ambiental necessária para o desenvolvimento da vida humana, foi proposto o estudo do clima urbano de Teodoro Sampaio/SP. Este trabalho visou compreender até que ponto o tamanho de uma cidade pode comprometer as condições climáticas e gerar um clima urbano específico, e qual a magnitude do fenômeno, pensando-se nas analogias internas entre os atributos geoecológicos do sítio, a morfologia e as funções urbanas, colaborando, assim, na solução dos problemas enfrentados no meio urbano. O estudo teve como objetivo principal de investigar as características térmicas e higrométricas intra-urbana e da zona rural próxima a Teodoro Sampaio/SP, cidade de pequeno porte, a fim de identificar a geração de diferenças térmicas e higrométricas em dias representativos das duas estações extremas, o verão e o inverno. 
Caracterização do clima urbano em Teodoro Sampaio/SP: Uma introdução Simone Scatolon Menotti Viana, Margarete Cristiane de Costa Trindade Amorim

Teodoro Sampaio está localizado a $22^{\circ} 53^{\prime}$ $25^{\prime \prime} \mathrm{S}$ e a $52^{\circ} 16^{\prime} 75^{\prime \prime} \mathrm{W}$, distante $112 \mathrm{Km}$ de Presidente Prudente e $672 \mathrm{Km}$ da capital São Paulo. O município de Teodoro Sampaio encontra-se no extremo oeste do Estado de São Paulo (Figura 1).

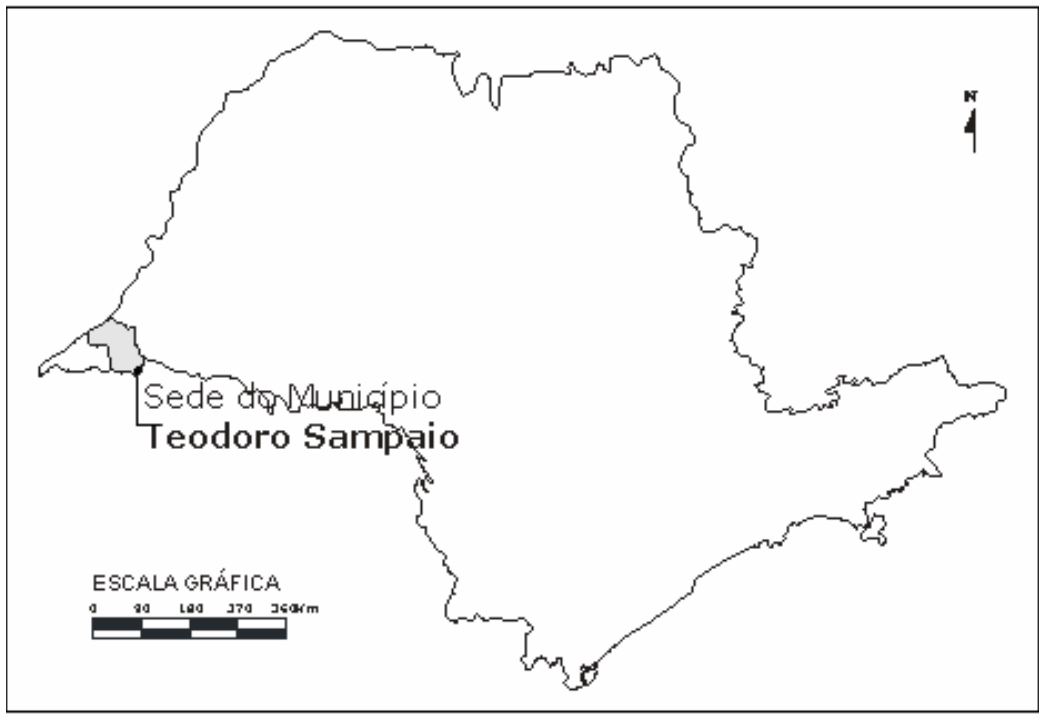

Figura 1 - Localização de Teodoro Sampaio no Estado de São Paulo

\section{PROCEDIMENTOS METODOLÓGICOS}

O estudo do clima urbano de Teodoro Sampaio teve como base de sustentação teóricoconceitual e metodológica as propostas formalizadas por Monteiro em 1976 e 1990. Estas propostas compõem uma estrutura teórica e metodológica para o estudo e compreensão do clima urbano. Nesta pesquisa foi trabalhado o S.C.U. (Sistema Clima Urbano) com ênfase ao subsistema termodinâmico que compreende o conforto térmico a partir do estudo das características da temperatura e umidade, nas suas variações diurnas e sazonais sob o espaço urbano.

Para o levantamento de campo foram realizadas coletas de dados com mini-abrigos meteorológicos. Os pontos foram selecionados a partir das características do relevo, da declividade e da hidrologia, sendo estas associadas ao tipo de uso e ocupação do solo (Figura 2).

A ocupação da malha urbana foi dividida em seis classes:
- área densamente construída, com vegetação arbórea ausente e pavimentação nas ruas;

- área densamente construída, com vegetação arbórea de grande porte em abundância e pavimentação nas ruas;

- área densamente construída, com vegetação arbórea de médio porte esparsa e ruas parcialmente pavimentadas;

- área densamente construída, com dois pavimentos, vegetação arbórea de médio porte e pavimentação nas ruas;

- construções esparsas, gramados e vegetação arbórea de grande porte em abundância e ruas sem pavimentação;

- construções esparsas, gramados e vegetação arbórea esparsa a ausente e ruas sem pavimentação.

As áreas densamente construídas se encontram localizadas próximas ao centro comercial da cidade. Estas áreas se distinguem pelo tipo de vegetação que possuem. As áreas menos construídas estão mais afastadas do centro e possuem menos 
vegetação. Quanto ao tipo de uso do solo, a cidade se organiza em comercial e residencial, principalmente. A partir da caracterização do uso e da ocupação do solo, associada ao tipo de relevo e a presença de vegetação foi possível escolher os pontos de coletas de dados. São eles:

- Vila São Paulo - área de construções esparsas, gramados e vegetação de grande porte em abundância. O uso do solo destina-se exclusivamente ao residencial;

- Prefeitura - área densamente construída com vegetação arbórea ausente. O uso solo é comercial;

- Odilon Ferreira - área densamente construída com vegetação arbórea de grande porte em abundância. O uso do solo é misto, sendo comercial e residencial;

- Vila Furlan - área densamente construída com vegetação arbórea de médio porte. $\mathrm{O}$ uso do solo é misto, sendo o residencial com mais predominância;

- Vila Minas Gerais - área densamente construída com dois pavimentos e vegetação arbórea de médio porte. Uso do solo exclusivamente residencial;

- Estação - área de construções esparsas, gramados e vegetação arbórea esparsa a ausente. Uso do solo residencial.

- Rio Paranapanema - área de vegetação esparsa e gramado, próxima ao Rio Paranapanema. $\mathrm{O}$ uso do solo destina-se as atividades rurais, como a pecuária e agricultura.

Os mini-abrigos meteorológicos foram constituídos de psicrômetros, ou seja, pares de termômetros (bulbo seco e bulbo úmido) para medidas de temperatura e umidade relativa do ar e fita de cetim fixada na parte inferior do mini-abrigo utilizada para indicar a direção do vento. A velocidade do vento foi estimada a partir da "Escala de Beaufort", o que possibilitou que a velocidade do vento fosse definida sem auxílio instrumental. Os mini-abrigos foram construídos de madeira com paredes duplas perfuradas para permitir a livre circulação do ar, foram encaixados em uma haste com $1,50 \mathrm{~m}$ do solo para que os termômetros não sofressem influência direta da radiação terrestre e suporte de madeira para encaixar os termômetros no interior do mini-abrigo. Esta metodologia foi utilizada por Sezerino e Monteiro (1990).

As leituras foram realizadas simultaneamente em sete pontos, sendo seis inseridos na malha urbana e um na área rural próxima, às $7 \mathrm{~h}, 9 \mathrm{~h}, 15 \mathrm{~h}$ e $21 \mathrm{~h}$, por 13 dias de janeiro de 2005 (17/01 a 29/01), dias representativos do verão - quente e chuvoso; e por oito dias de julho de 2005 (06/07 a 13/07), dias representativos do inverno - com temperatura mais baixa e seco.

Ao término dos trabalhos de campo as leituras coletadas foram digitadas e organizadas em tabelas, na planilha eletrônica Excel . Com a utilização do aplicativo Surfer for Windows, os dados de temperatura do ar foram espacializados por meio da geração de isotermas para melhor visualização dos resultados obtidos, o que permitiu construir um perfil das condições térmicas e higrométricas intra-urbana. Para a melhor compreensão do comportamento da temperatura foi realizada a análise dos sistemas atmosféricos regionais através das cartas sinóticas de superfície e das imagens de satélite Goes disponibilizadas no sítio da marinha do Brasil e no sítio do INPE². 
Caracterização do clima urbano em Teodoro Sampaio/SP: Uma introdução Simone Scatolon Menotti Viana, Margarete Cristiane de Costa Trindade Amorim

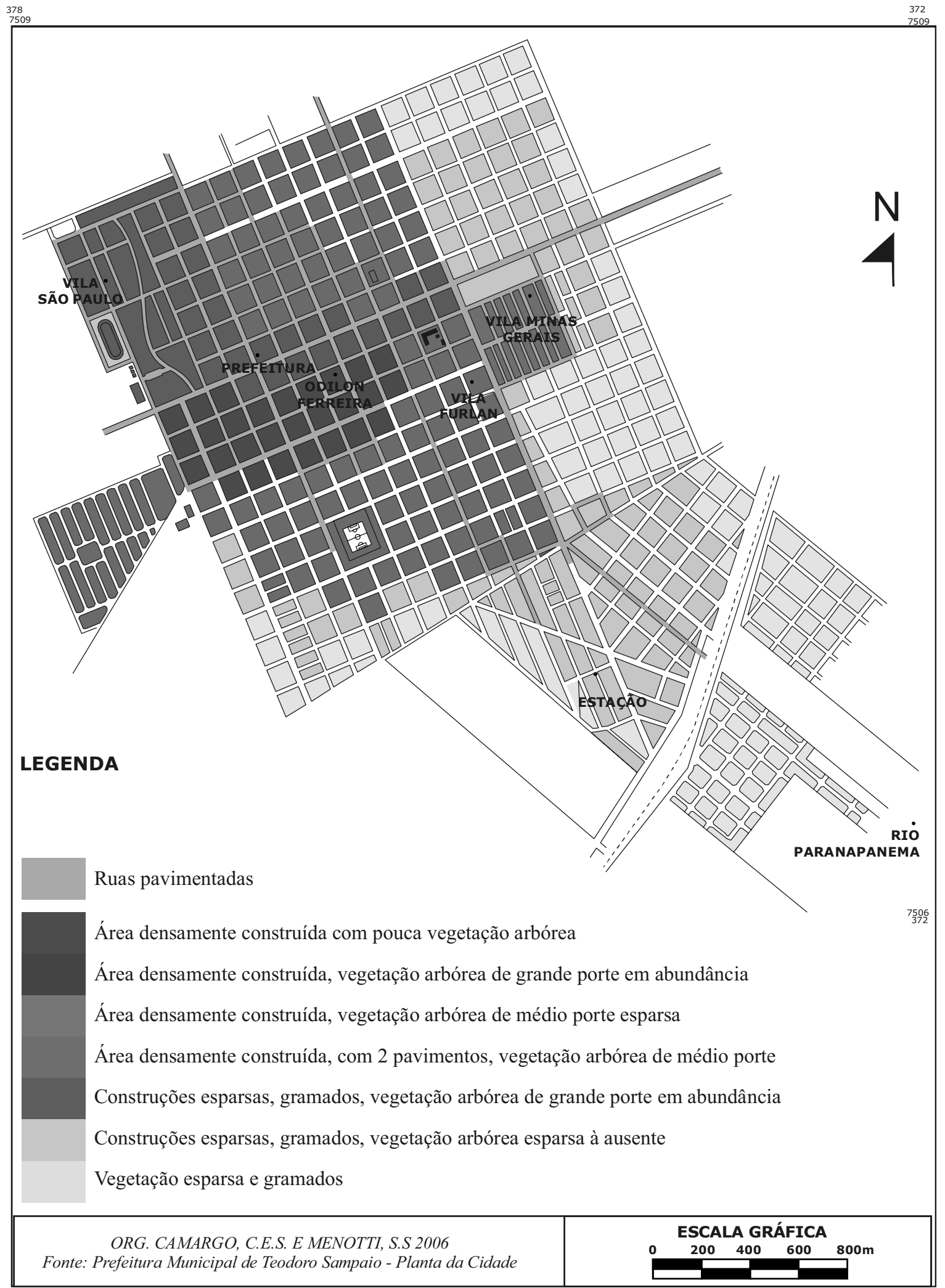




\section{O CLIMA URBANO DE TEODORO SAMPAIO}

O extremo Oeste paulista é uma região de alternância de massas tropicais e polares. A participação da Frente Polar Atlântica é decisiva na gênese das chuvas, ficando a região sujeita às freqüentes invasões de frentes frias, mesmo na primavera e verão, o que gera um período com mais chuvas e umidade.

A passagem de massas polares e de ondas de aquecimento pré-frontal ocasiona ritmos diferenciados para a temperatura, podendo ocasionar geadas no inverno. Durante o outono e inverno, os sistemas estabilizadores do tempo provocam diminuição das chuvas e ocasionam um período mais seco. (BARRIOS \& SANT'ANNANETO, 1996, p.9).

Cabe destacar a atuação das Frentes Frias, da Massa Polar Atlântica, da Massa Tropical Atlântica, da Massa Tropical Continental e da Massa Equatorial Continental, como sistemas principais na gênese do tempo atmosférico em Teodoro Sampaio.

No verão, os sistemas frontológicos acarretam aumento na precipitação e a massa de ar polar, mesmo que tropicalizada provoca estabilidade no tempo. Já a massa Tropical Atlântica atua com mais magnitude no verão trazendo instabilidades no tempo atmosférico devido ao aquecimento de suas camadas mais inferiores que originam células convectivas que promovem o aumento da nebulosidade e precipitações de ordem local, principalmente nos fins de tarde. A massa de ar Equatorial Continental, quente e úmida, proveniente da região amazônica percorre o território nacional e chega até o Oeste Paulista atraída pela atuação de frentes frias que deixam o tempo instável. Nos dois primeiros dias, existe a formação de desenvolvidos cúmulos nimbos o que os meteorologistas denominam de Complexo Convectivo de Mesoescala, que freqüentemente resulta em tempestades locais ou até regionais.

O mês de julho é representativo do inverno para a região de Teodoro Sampaio; a temperatura tende a ser mais baixa com pouca ou ausência de precipitação o que caracteriza um período mais frio e seco. Essas condições de tempo são frutos dos sistemas atmosféricos que atuam nesse período. No período do inverno, as invasões polares são mais freqüentes e intensas. As Frentes Frias e a Massa de ar Polar adentram a região com mais facilidade e magnitude devido às condições favoráveis de frontogênese.

A Massa de ar Polar traz estabilidade para o tempo e queda na temperatura e pode provocar geadas na região. Ainda, a atuação da Massa de ar Polar provoca aumento nas amplitudes térmicas diárias.

A Massa de ar Polar, durante o inverno, tende a permanecer por mais tempo sobre a região, assim com o passar dos dias o ar polar enfraquece, ganha temperatura e perde pressão atmosférica, transformando-se na Massa de ar Polar velha.

A Massa de ar Tropical também pode atuar neste período e causar estabilidade no tempo atmosférico durante o inverno devido ao pouco aquecimento das suas porções mais inferiores, o que dificulta a formação de nuvens e precipitação.

O clima de uma região é estabelecido a partir da análise conjunta de fatores estáticos e dinâmicos. Entendem-se como fatores estáticos a latitude e a longitude associadas às formas do relevo e como fatores dinâmicos a circulação das massas de ar. (NIMER 1989, apud FARIA et al. 2006).

Faria et al. (2006) propuseram uma classificação climática para a região de Teodoro Sampaio com base nesses fatores estáticos e dinâmicos, associados à análise de diversos elementos climáticos (temperatura, evapotranspiração potencial, precipitação, radiação solar, pressão atmosférica e direção e velocidade do vento) contemplando uma série histórica de 26 anos (1977 a 2002). Com base na análise da série histórica de 26 anos (1977 a 2002), os autores apresentaram os seguintes dados para a região: 
Caracterização do clima urbano em Teodoro Sampaio/SP: Uma introdução Simone Scatolon Menotti Viana, Margarete Cristiane de Costa Trindade Amorim

A temperatura média anual é de 21,9ÚC, sendo que a temperatura média do mês mais quente foi de 25,3ÚC e a do mês mais frio 17,2ÚC. Com relação à precipitação, anualmente a média foi de $1370 \mathrm{~mm}$, sendo que o mês mais chuvoso foi de $212 \mathrm{~mm}$ e o mais seco $37 \mathrm{~mm}$.

A evapotranspiração potencial é uma das maiores do Estado, $1340 \mathrm{~mm}$, provavelmente conseqüência da proximidade do Rio Paranapanema e os cerca de 35.000 ha da vegetação presente no Parque Estadual Morro do Diabo. A região contribui com grande quantidade de vapor d'água para a atmosfera, evidenciada pela umidade relativa do ar, ao redor dos $80 \%$ na média e acima de $90 \%$ na máxima, mesmo nos meses considerados secos.

A radiação solar global na região do Pontal, bastante elevada durante todos os meses do ano, em média, $17,2 \mathrm{~W} / \mathrm{m}^{2}$ ao mês, o que contribui para que haja uma grande evaporação, mesmo nos meses secos e frios. A pressão atmosférica está em torno dos 980 milibares, em média, atingindo valores um pouco mais elevados nos meses mais frios.

A velocidade do vento pode ser classificada como de fraca intensidade, sendo a média anual de $1,09 \mathrm{~m} / \mathrm{s}$ ou $3,9 \mathrm{~km} / \mathrm{hora}$. A direção predominante é a do quadrante Norte.
Diante desses dados e com base na classificação climática proposta por Köppen, Faria et al. (2006), concluíram que o clima da região é o $C f a$, úmido em todas as estações do ano e com verões quentes, não havendo uma estação seca.

As observações - mensurações atmosféricas nos pontos fixos, com levantamentos diurnos e noturnos, em horários pré-estabelecidos $(7 \mathrm{~h}, 9 \mathrm{~h}, 15 \mathrm{~h}$ e 21h), dos elementos climáticos, permitiram detectar algumas diferenças térmicas e higrométricas, em dias representativos das duas estações extremas, verão e inverno, numa cidade de pequeno porte.

A ocupação do solo associada à presença de vegetação foram decisivas na geração e identificação das anomalias térmicas e higrométricas encontradas na cidade de Teodoro Sampaio. A altitude e exposição de vertentes se mostraram com pouca ou nenhuma influência, devido à pequena diferença altimétrica entre os pontos e a cidade estar praticamente implantada na mesma vertente.

Às $7 \mathrm{~h}$ as ilhas de calor se configuraram tanto no verão como no inverno com diferença apenas nas magnitudes e nos sistemas atmosféricos atuantes (Tabela 1). No verão, a magnitude pode ser classificada como de fraca intensidade e, no inverno, como de moderada intensidade.

Tabela 1 - Magnitudes máximas da ilha de calor às $7 \mathrm{~h}$

\begin{tabular}{cccccc}
\hline VER ÃO & INVERNO & \\
\hline Dia & Magnitude & $\begin{array}{c}\text { Sistema } \\
\text { atmosférico }\end{array}$ & Dia & Magnitude & $\begin{array}{c}\text { Sistema } \\
\text { atmosférico }\end{array}$ \\
\hline $26 /$ jan & $2,2^{\circ} \mathrm{C}$ & Frente Fria & $10 /$ jul & $3,8^{\circ} \mathrm{C}$ & $\mathrm{MPV}^{3}$ \\
\hline
\end{tabular}

No verão, o ponto mais aquecido e seco foi o Odilon Ferreira, sendo que a magnitude da ilha de calor máxima foi de $2,2^{\circ} \mathrm{C}$ (Tabela 1). As imediações da Rua Odilon Ferreira têm como características principais elevados índices de construções, ruas asfaltadas e vegetação de grande porte. Devido à inércia calórica dos materiais utilizados na construção das casas e ruas, o ambiente continuou aquecido e esses materiais permaneciam devolvendo o calor armazenado no dia anterior para a atmosfera até as

\footnotetext{
3 MPV - Massa Polar Velha
} 
primeiras horas do dia. Cabe dizer que, em alguns dias, o ponto rural adquiriu valores de temperatura similares aos observados nas imediações da Rua Odilon Ferreira, na atuação de um sistema de baixa pressão que provocou aumento na nebulosidade (Figura 3).

No verão, as ilhas de frescor formaram-se na Vila São Paulo, Vila Furlan e Estação, com maior incidência para a Vila São Paulo (Figura 3), local de maior índice de vegetação de grande porte da cidade, gramados e vegetação nos quintais, principalmente os jardins. E ainda, é o ponto mais elevado e às $7 \mathrm{~h}$, devido aos raios solares até então próximos da linha do horizonte, a superfície terrestre encontrava-se sempre na sombra, conseqüência das construções e da própria vegetação servindo como um escudo para a incidência dos raios solares. Os demais pontos, Vila Furlan e Estação, são bem arborizados, com ruas sem pavimentação e ausência de raios solares diretos na superfície.

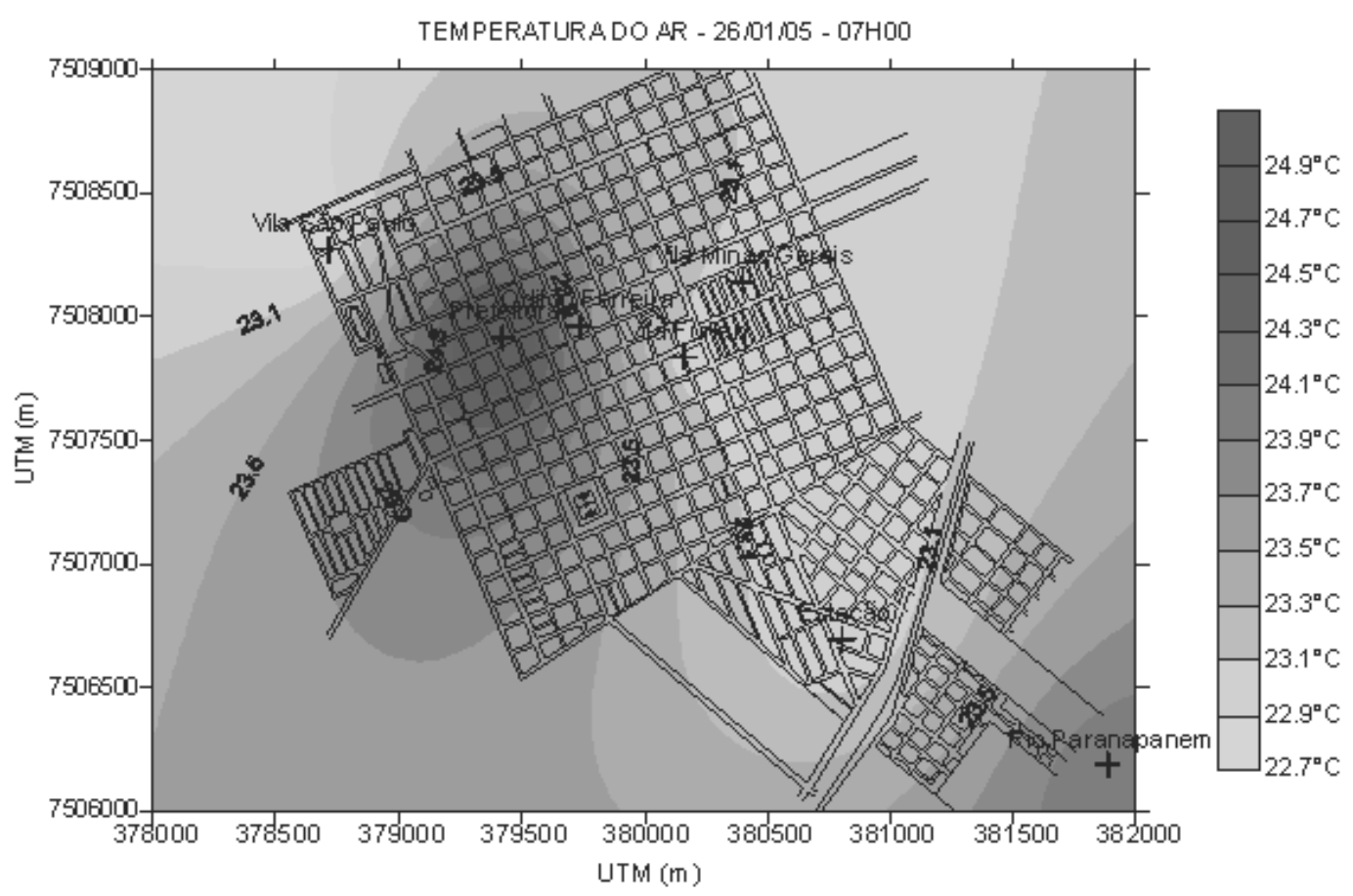

Figura 3 - Isotermas às $7 \mathrm{~h}$ - padrão predominante no verão

As ilhas secas se formaram na Prefeitura e Odilon Ferreira e a ilhas de umidade entre a Vila Furlan e Estação (Figura 4); o maior destaque deve ser dado às proximidades da Rua Odilon Ferreira, a ilha seca se formou juntamente com a ilha de calor, local densamente construído, ruas pavimentadas e vegetação de grande porte, embora com ausência de gramados e vegetação em quintais, como os jardins.
Nesse caso, para esse horário, a vegetação não auxiliou na elevação das taxas de umidade, ao passo que as ilhas de umidade se formaram nos locais em que se configuraram as ilhas de frescor (Vila São Paulo, Vila Furlan e Estação). Estas têm como características principais, menor densidade de construções, ruas sem pavimentação e maior índice de gramados e vegetação nos quintais e jardins. 
Caracterização do clima urbano em Teodoro Sampaio/SP: Uma introdução Simone Scatolon Menotti Viana, Margarete Cristiane de Costa Trindade Amorim

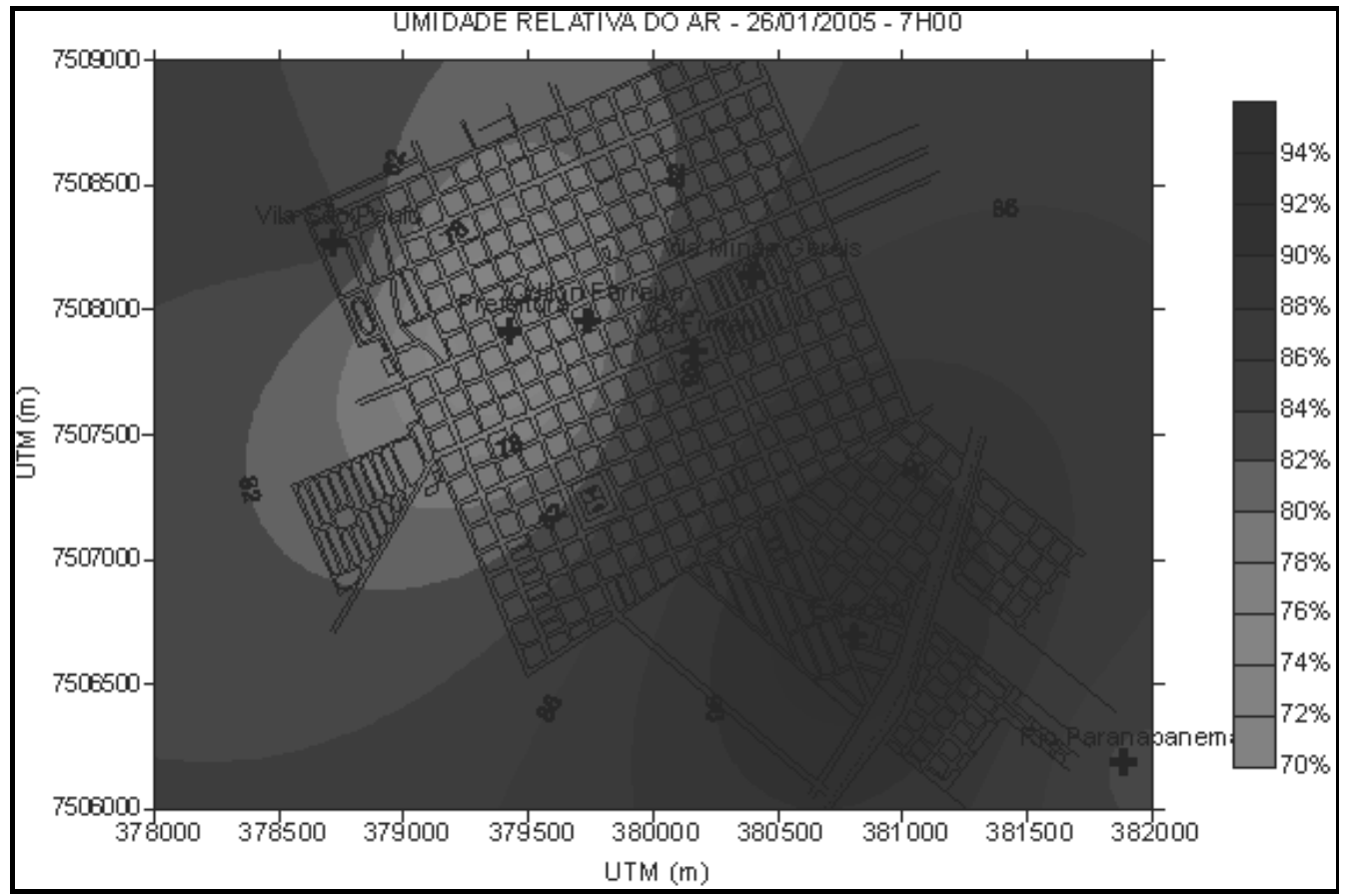

Figura 4 - Isoígras às $7 \mathrm{~h}$ - padrão predominante no verão

Durante o verão e início da manhã, a vegetação de grande porte não teve grande auxílio na diminuição da magnitude das ilhas de calor e nas ilhas secas, fato que aconteceu nas áreas com gramados e jardins bem cuidados (Vila São Paulo) e ruas sem pavimentação e solo nu associados aos gramados e jardins das casas (Vila Furlan e Estação). Assim nestas áreas, a ocupação do solo contribuiu para o desenvolvimento das ilhas de umidade e de frescor. Cabe salientar que, as áreas com gramados, jardins e solo nu apresentavam-se molhadas pelo orvalho e, em alguns dias, pela chuva ocorrida durante a noite.

No inverno, a magnitude da ilha de calor foi de $3,8^{\circ} \mathrm{C}$ (Tabela 1 ) e oscilou entre Prefeitura e Vila Furlan com menor intensidade. No inverno, a definição do núcleo da ilha de calor se desfez e houve inversão no padrão definido no ponto Odilon Ferreira. No verão, o ponto apresentou a formação de uma ilha de calor e, no inverno, o fenômeno desapareceu e houve a formação de uma ilha de frescor.

Durante a noite, sob condições sinóticas de baixa velocidade do vento ou calmaria, as áreas densamente construídas e as ruas pavimentadas armazenam maior quantidade de calor do que as áreas com menor densidade de construções e sem pavimentação, resultando na formação de ilhas de calor. Este fato pode ser verificado na ilha de calor que se formou sobre o ponto da Prefeitura em dias representativos do inverno (Figura 5). Assim, no início da manhã (7h), as maiores temperaturas registradas em área densamente construída decorrem do calor armazenado nas edificações e ruas pavimentadas, assim apresentando comportamento térmico idêntico ao apresentado nas proximidades da Rua Odilon Ferreira no verão. 
Caracterização do clima urbano em Teodoro Sampaio/SP: Uma introdução Simone Scatolon Menotti Viana, Margarete Cristiane de Costa Trindade Amorim

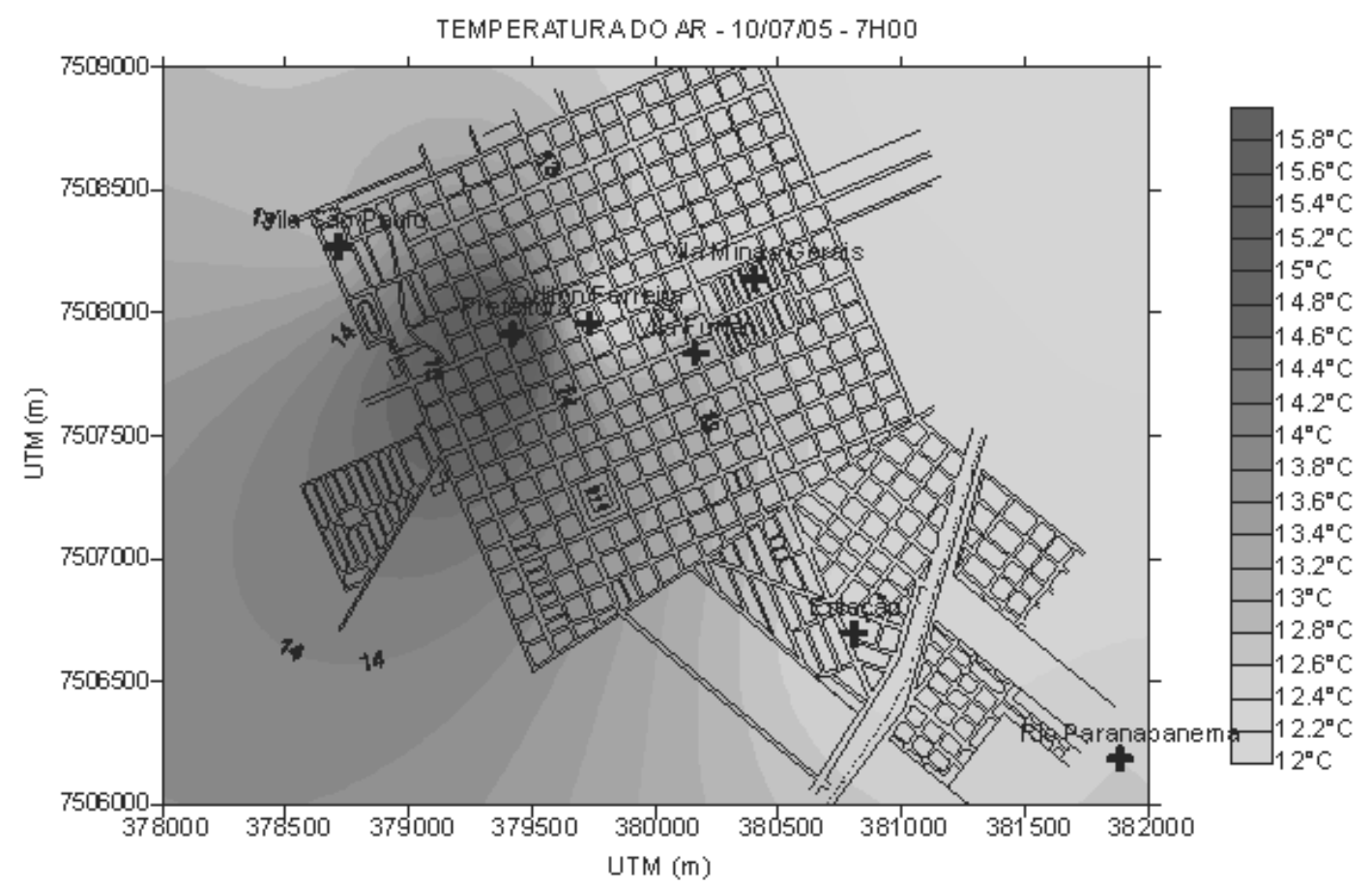

Figura 5 - Isotermas às $7 \mathrm{~h}$ - padrão predominante no inverno

No inverno, nas imediações da Rua Odilon Ferreira, houve diminuição da temperatura e configuração de uma ilha de frescor. Juntamente com Odilon Ferreira, a ilha de frescor se formou na Vila São Paulo e com mais persistência na Estação (Figura 5). A ilha de frescor formada na área de Odilon Ferreira é conseqüência do "efeito sombra", ocorrido na Vila São Paulo na pesquisa de verão. Neste caso a vegetação e a alta densidade de construções dificultaram a penetração dos raios solares resultando na diminuição da temperatura. (Em todos os dias da pesquisa o abrigo estava na sombra).

As ilhas de umidade, durante o inverno, não se configuraram juntamente com as ilhas de frescor como no verão. Elas se formaram na Estação, durante o enfraquecimento da frente fria e consolidação do ar polar (Figura 6), e na Prefeitura na passagem do sistema frontal e com a atuação da massa Polar Atlântica a ilha de umidade desapareceu e se formou uma ilha seca. 
Caracterização do clima urbano em Teodoro Sampaio/SP: Uma introdução Simone Scatolon Menotti Viana, Margarete Cristiane de Costa Trindade Amorim

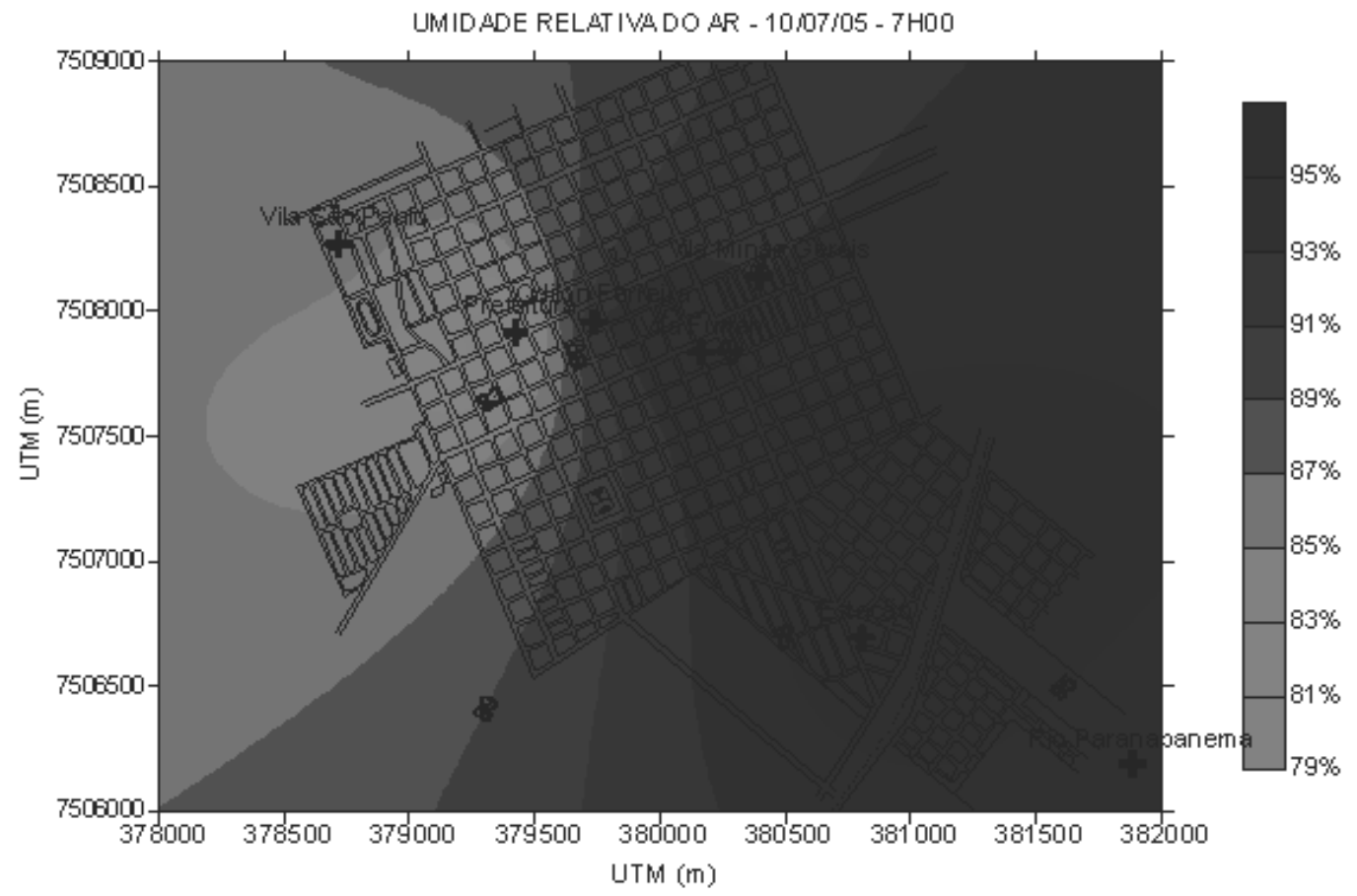

Figura 6 - Isoígras às $7 \mathrm{~h}$ - padrão predominante no inverno

Às 9h, tanto as áreas intra-urbanas como a área rural iniciam o seu aquecimento diurno, embora as áreas intra-urbanas levem mais tempo para se aquecer do que a área rural, em decorrência da cobertura do solo e da presença de construções que servem como obstáculos e impedem a chegada da radiação solar até a superfície terrestre. $\mathrm{O}$ aquecimento iniciado às $9 \mathrm{~h}$ atinge o máximo às $15 \mathrm{~h}$, quando acontece o máximo do aquecimento diurno.

Às 9h, no verão, a ilha de calor ganhou magnitude com relação à apresentada às $7 \mathrm{~h} \mathrm{e}$, no inverno, perdeu magnitude (Tabela 2); ambas as ilhas podem ser classificadas como de moderada intensidade.

Tabela 2 - Magnitudes máximas da ilha de calor às $9 \mathrm{~h}$

\begin{tabular}{cccccc}
\hline & VERÃO & & & INVERNO & \\
\hline Dia & Magnitude & $\begin{array}{c}\text { Sistema } \\
\text { atmosférico }\end{array}$ & Dia & Magnitude & $\begin{array}{c}\text { Sistema } \\
\text { atmosférico }\end{array}$ \\
\hline $25 /$ jan & $3,9^{\circ} \mathrm{C}$ & Frente Fria & $9 /$ jul & $2,9^{\circ} \mathrm{C}$ & MPV \\
\hline
\end{tabular}

Nesse horário houve uma mudança no núcleo de formação da ilha de calor, tanto no verão como no inverno. Essa mudança no núcleo foi provocada por alterações no padrão de distribuição espacial da temperatura. As áreas menos urbanizadas, embora distantes do centro comercial da cidade e a área rural apresentaram elevação na temperatura e declínio nas taxas de umidade relativa com relação às apresentadas às $7 \mathrm{~h}$ (Figura 7). 
Caracterização do clima urbano em Teodoro Sampaio/SP: Uma introdução

Simone Scatolon Menotti Viana, Margarete Cristiane de Costa Trindade Amorim

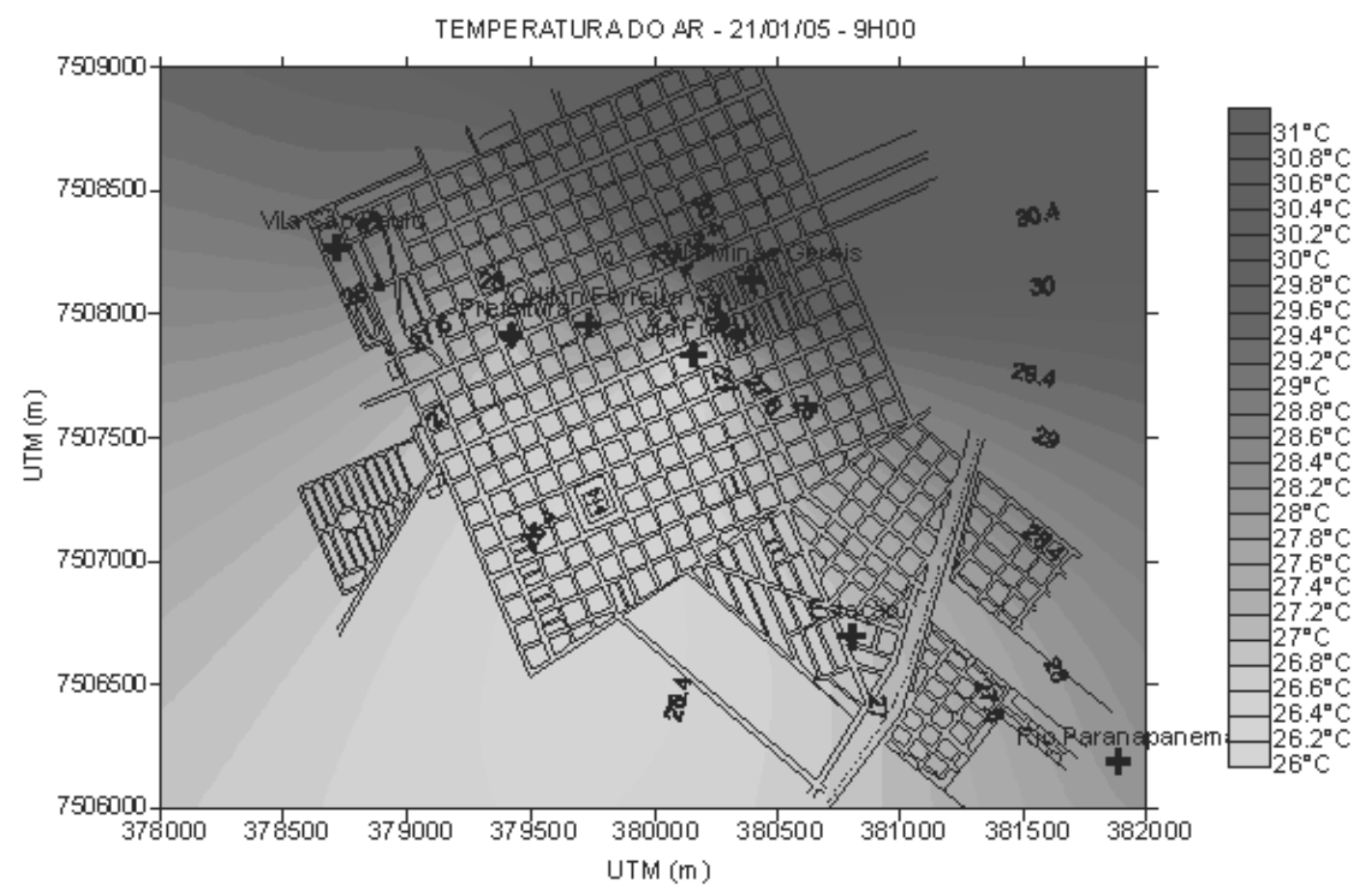

Figura 7 - Isotermas às $9 \mathrm{~h}$ - padrão predominante no verão

No verão, a ilha de calor que se delineou próxima ao Rio Paranapanema é decorrência do aquecimento mais acelerado das áreas rurais que são mais livres de construções. Os materiais constituintes dessas áreas estão recebendo os raios solares mais diretamente desde o nascer do sol e devido o coeficiente de reflexão ser maior, principalmente o da grama no ponto rural, começa a devolução do calor para a atmosfera de maneira mais rápida do que nas áreas construídas. As ilhas de frescor se desenvolveram na Vila Furlan e Prefeitura com menor aparecimento. No Bairro da Estação e Vila São Paulo, o fenômeno perdeu intensidade.

As ilhas úmidas foram observadas nos pontos Vila Furlan e Estação, e a ilha seca se formou basicamente no ponto Odilon Ferreira, evidenciando o comportamento observado às $7 \mathrm{~h}$ (Figura 8 ). 
Caracterização do clima urbano em Teodoro Sampaio/SP: Uma introdução Simone Scatolon Menotti Viana, Margarete Cristiane de Costa Trindade Amorim

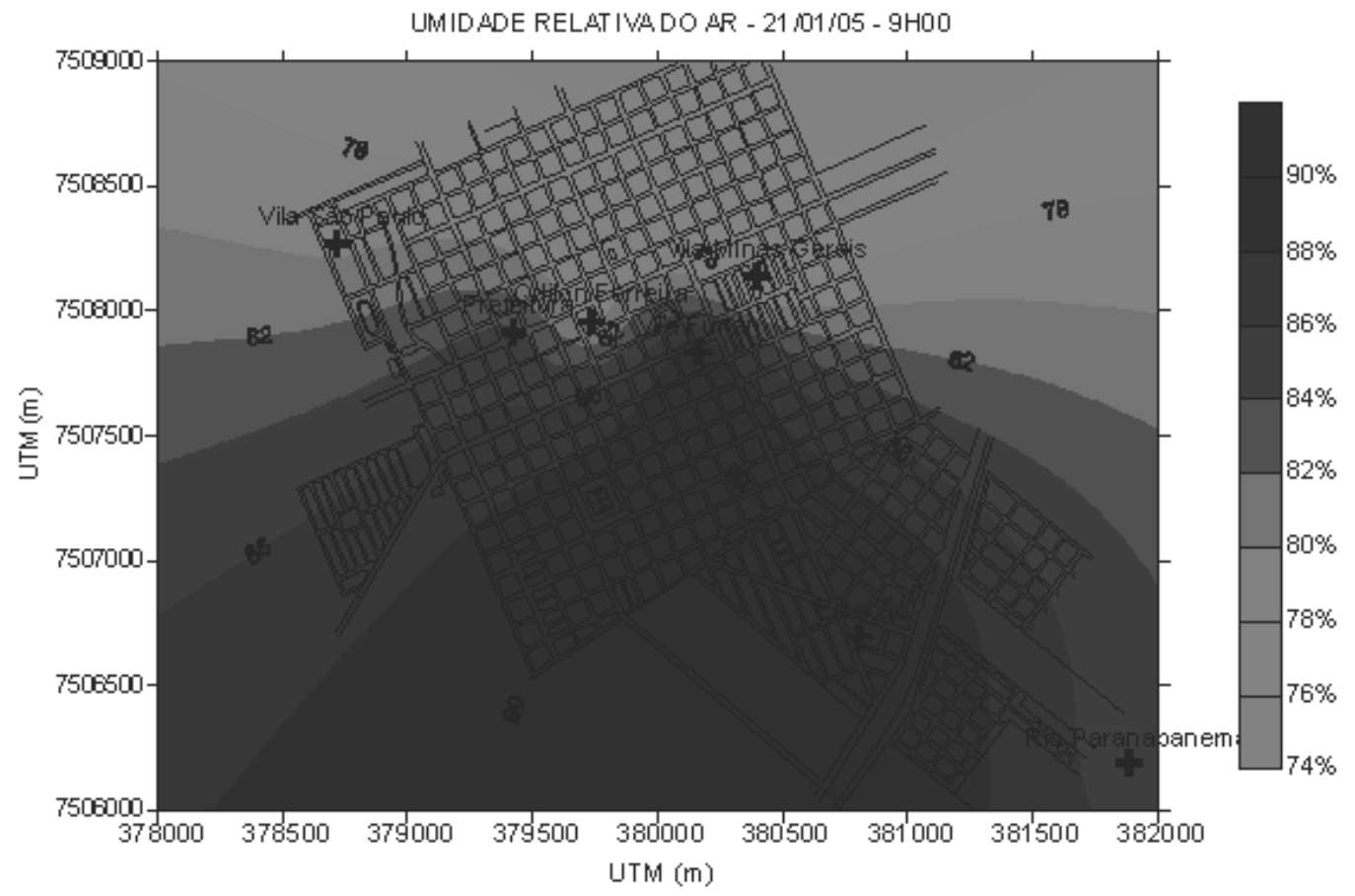

Figura 8 - Isoígras às $9 \mathrm{~h}$ - padrão predominante no verão

No inverno, as ilhas de calor se configuraram na Estação e Vila Minas Gerais e na área rural (Rio Paranapanema), com comportamento similar ao desenvolvido no verão. A configuração da ilha de frescor apresentou oscilação entre Vila São Paulo, Prefeitura e Estação. Na Vila São Paulo e Prefeitura, os raios solares ainda não atingem de maneira direta a superfície, ocasionando uma demora no aquecimento do ar, o que favoreceu a formação das ilhas de frescor. Especificamente, na Estação, durante a passagem da frente fria, configurou-se a ilha de frescor e com a atuação do ar polar na área passou a configurar uma ilha de calor (Figura 9).

As ilhas de umidade foram observadas na Prefeitura. As ilhas secas se formaram na Vila São Paulo, na Rua Odilon Ferreira e no Bairro da Estação, assim apresentando um comportamento inverso ao apresentado no verão (Figura 10). 
Caracterização do clima urbano em Teodoro Sampaio/SP: Uma introdução

Simone Scatolon Menotti Viana, Margarete Cristiane de Costa Trindade Amorim

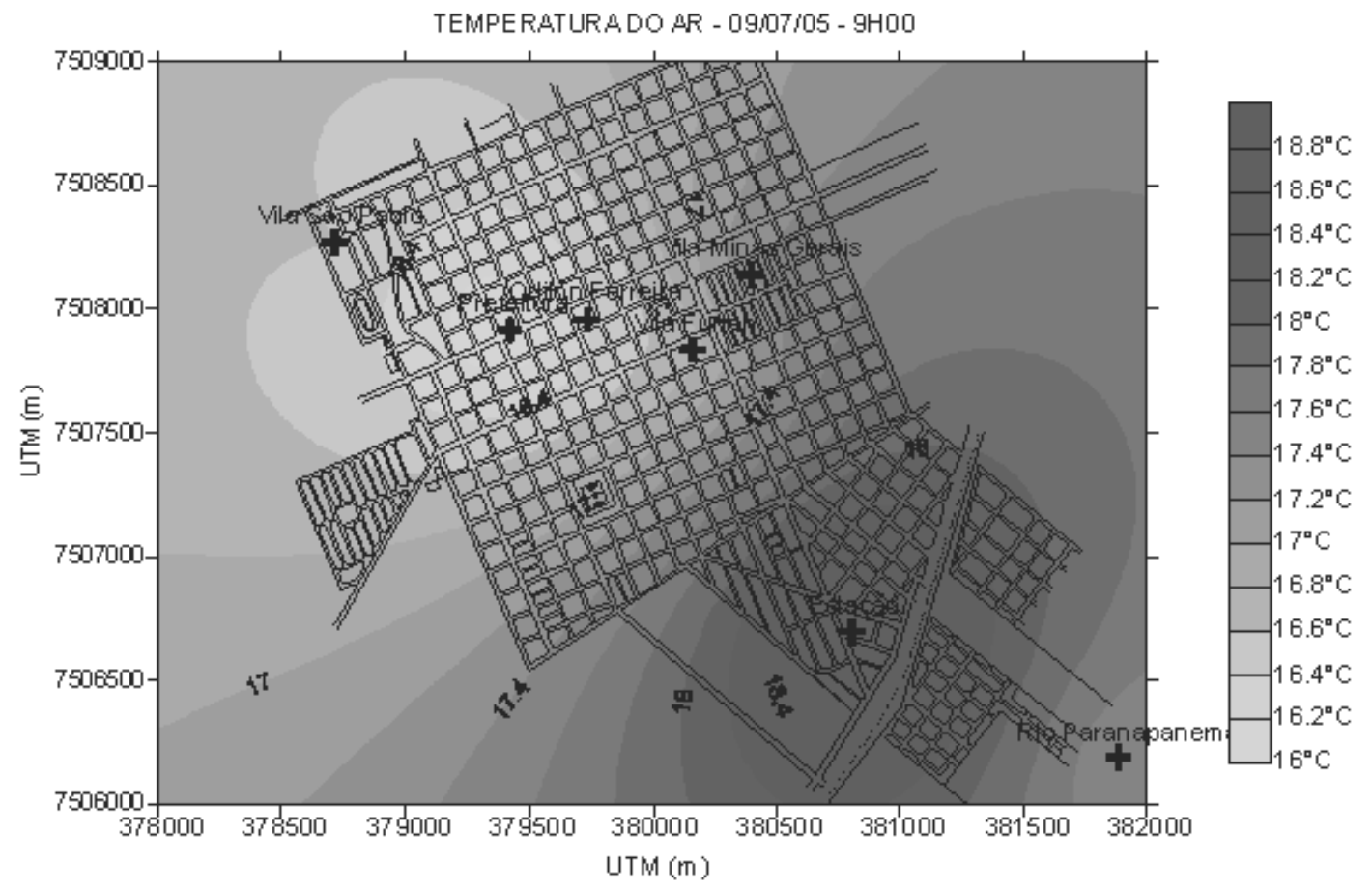

Figura 9 - Isotermas às $9 \mathrm{~h}$ - padrão predominante no inverno

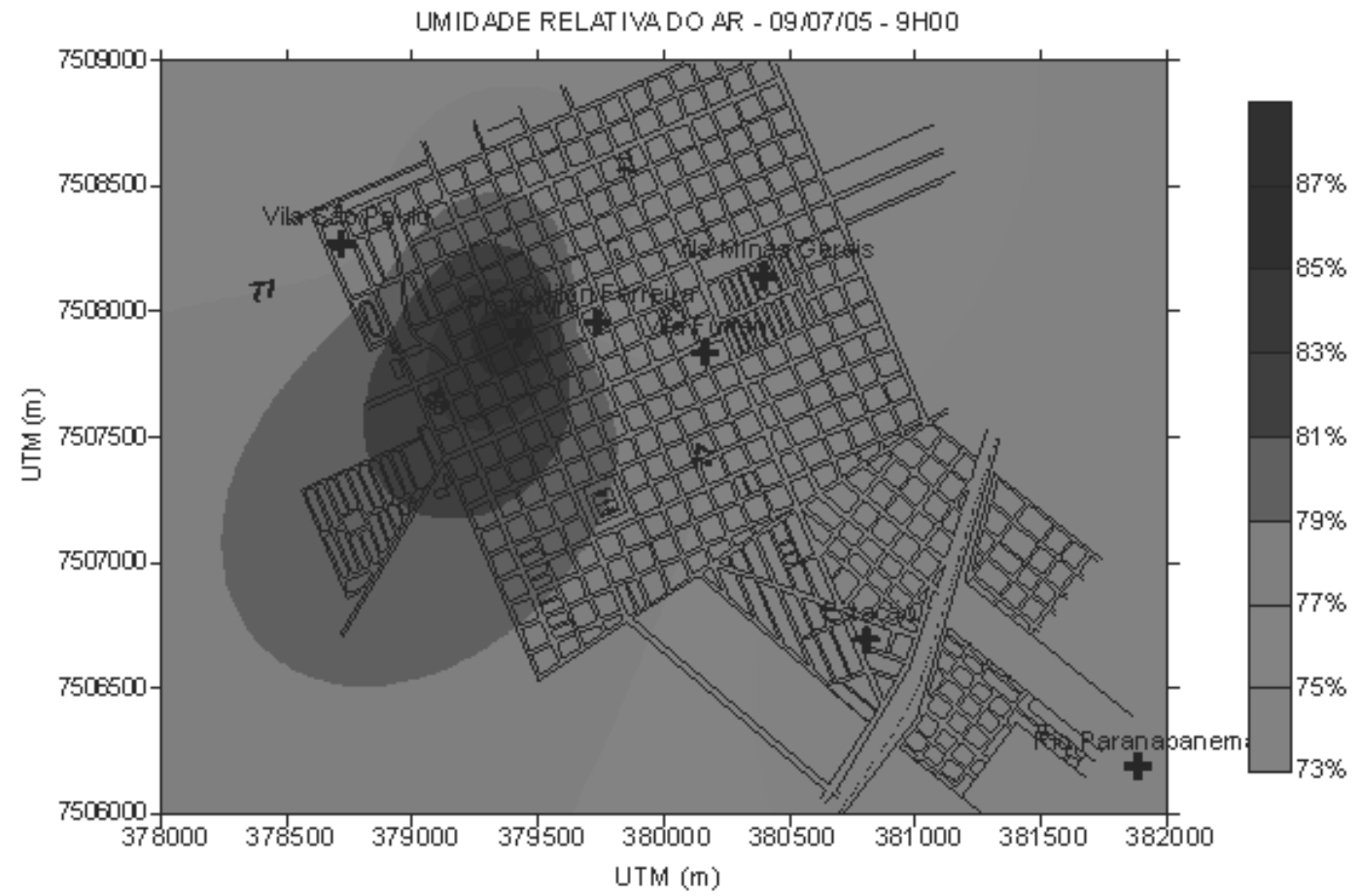

Figura 10 - Isoígras às $9 \mathrm{~h}$ - padrão predominante no inverno

Sociedade \& Natureza, Uberlândia, 20 (2): 19-42, DEZ. 2008 
Caracterização do clima urbano em Teodoro Sampaio/SP: Uma introdução Simone Scatolon Menotti Viana, Margarete Cristiane de Costa Trindade Amorim

Às $15 \mathrm{~h}$ tanto no verão como no inverno, a temperatura do ar atingiu o seu máximo e as taxas de umidade relativa, o seu valor mínimo; isso é conseqüência do maior valor de radiação terrestre devolvida para a atmosfera. No verão e inverno, as áreas mais aquecidas ficaram bem definidas sendo, respectivamente, no Rio Paranapanema e na Vila Minas Gerais.
Às $15 \mathrm{~h}$, no verão e no inverno, as amplitudes térmicas (Tabela 3) aumentaram com relação às observadas às $9 \mathrm{~h}$ (Tabela 2). Em ambas as estações, as ilhas de calor foram classificadas como sendo de forte intensidade.

Tabela 3 - Magnitudes máximas da ilha de calor às $15 \mathrm{~h}$

\begin{tabular}{cccccc}
\hline VER ÃO & INVERNO & \\
\hline Dia & Magnitude & $\begin{array}{c}\text { Sistema } \\
\text { atmosférico }\end{array}$ & Dia & Magnitude & $\begin{array}{c}\text { Sistema } \\
\text { atmosférico }\end{array}$ \\
\hline 18/jan & $5,4^{\circ} \mathrm{C}$ & $($ ZCAS $)$ & $6 /$ jul & $4^{\circ} \mathrm{C}$ & Frente Fria - MPA ${ }^{4}$ \\
\hline
\end{tabular}

No verão, a ilha de calor que se formou no ponto Rio Paranapanema fez desaparecer a ilha de calor urbana por seis dias dos treze estudados (Figura 11). Esse comportamento pode ser explicado pela influência direta dos sistemas atmosféricos atuantes que nesses dias provocaram chuva, principalmente no final da manhã. A chuva proporcionou ligeira queda nas temperaturas, principalmente na área urbana, e aumento na umidade relativa do ar, mas no decorrer da tarde, com algumas aberturas de sol, a temperatura se elevou mais rapidamente no ponto rural do que no meio urbano.
As ilhas de frescor e de umidade, no verão, se formaram na Vila Furlan e Estação, e a ilha seca se formou apenas na área de Odilon Ferreira, assim evidenciando as ilhas encontradas no período da manhã durante o verão. Nesse horário, as áreas com menor densidade de construções, ruas sem pavimentação e vegetação arbórea e gramados apresentaram-se menos aquecidas e úmidas. Já a área densamente construída, com ruas asfaltadas e com vegetação arbórea, apresentou-se com menos umidade devido à inexistência de gramados e jardins, embora não tenha adquirido os maiores valores de temperatura. (Figura 12)

\footnotetext{
4 MPA - Massa Polar Atlântica
} 
Caracterização do clima urbano em Teodoro Sampaio/SP: Uma introdução

Simone Scatolon Menotti Viana, Margarete Cristiane de Costa Trindade Amorim

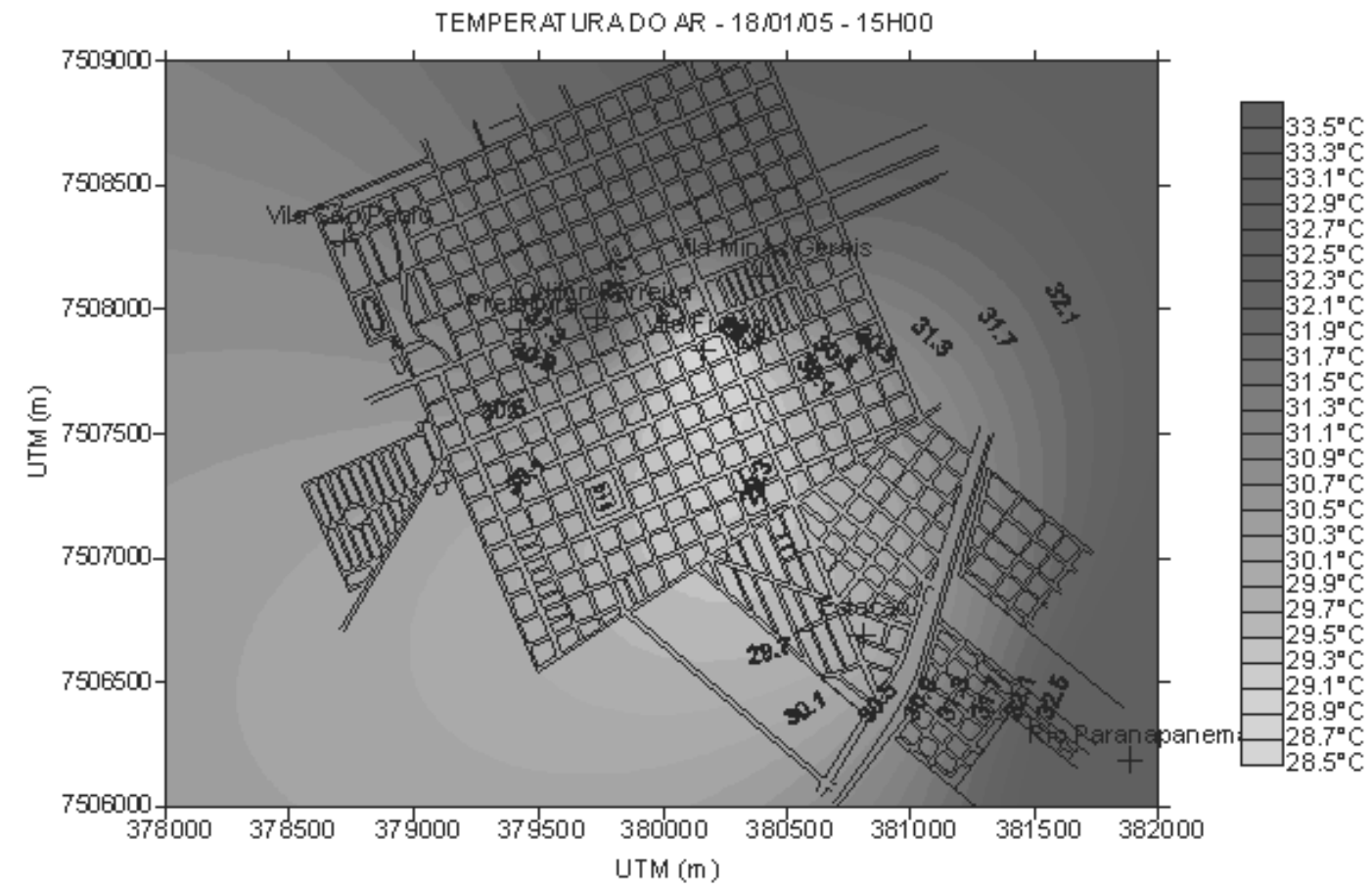

Figura 11 - Isotermas às $15 \mathrm{~h}$ - padrão predominante no verão

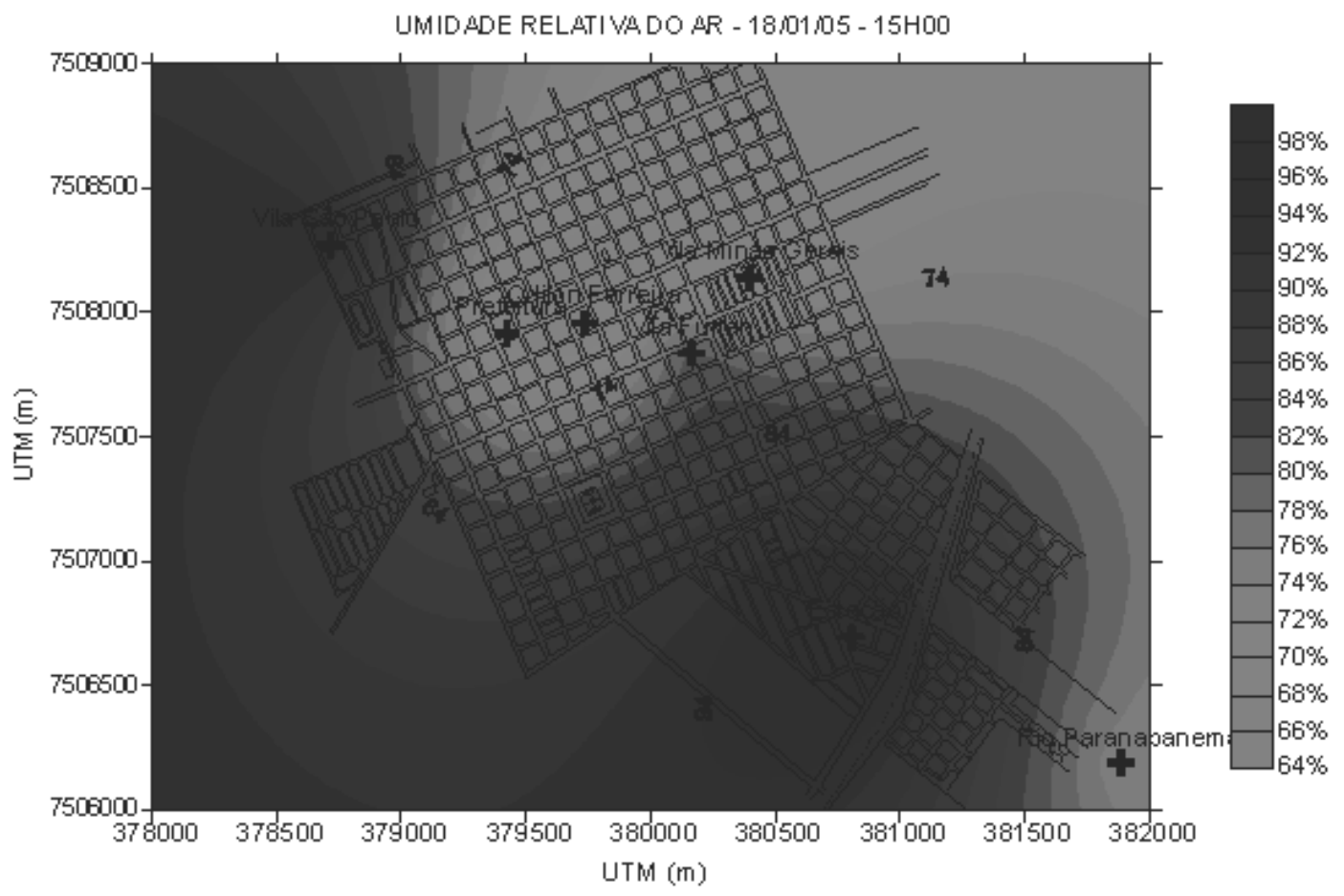

Figura 12 - Isoígras às $15 \mathrm{~h}$ - padrão predominante no verão

Sociedade \& Natureza, Uberlândia, 20 (2): 19-42, DEZ. 2008 
Caracterização do clima urbano em Teodoro Sampaio/SP: Uma introdução Simone Scatolon Menotti Viana, Margarete Cristiane de Costa Trindade Amorim

No inverno, a ilha de calor se mostrou mais bem definida no ponto Vila Minas Gerais (Figura 13), devido, primeiro às condições de ocupação do solo, alta densidade de construções, inclusive casas de dois pavimentos, ruas pavimentadas e pouca vegetação e em segundo, as condições do tempo atmosférico, céu limpo, baixa velocidade do vento e pouca nebulosidade. Demonstrando a capacidade de estocagem e conservação de energia nas áreas densamente construídas, mesmo distantes do centro da cidade, e que às $15 \mathrm{~h}$ estão devolvendo para atmosfera parte do calor armazenado desde o período da manhã. A ilha de frescor se formou especificamente na Prefeitura (Figura 13) devido a presença de vegetação rasteira, ou seja, os gramados e pequenos arbustos decorativos presentes na Praça da Prefeitura, o que auxiliou na diminuição da temperatura.

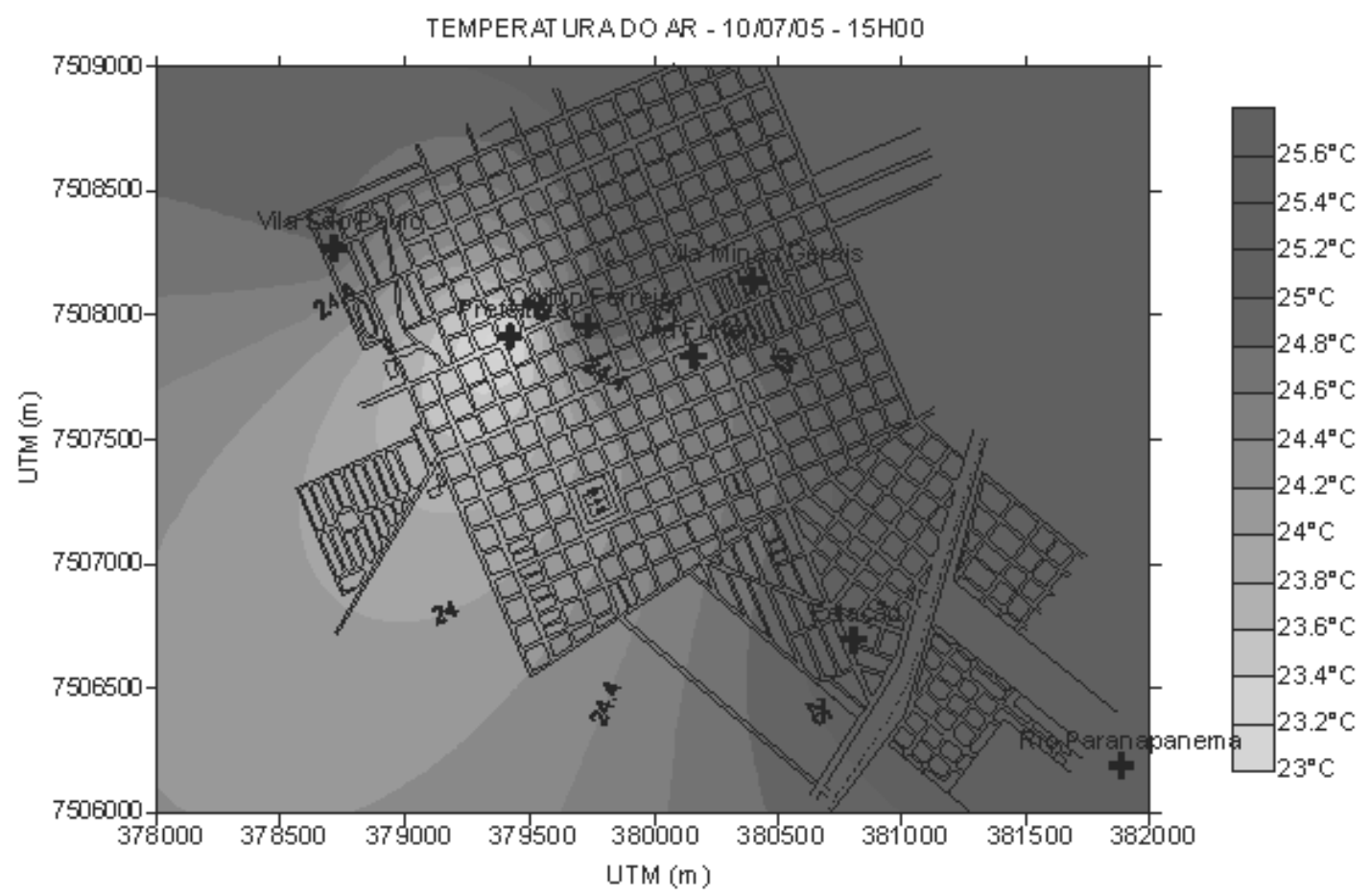

Figura 13 - Isotermas às $15 \mathrm{~h}$ - padrão predominante no inverno

A ilha de umidade se configurou na Estação, área com presença significativa de vegetação arbórea, gramados e jardins, menor densidade de construção e ruas não pavimentadas. A ilha seca se delineou exclusivamente no ponto Odilon Ferreira, como no verão (Figura 14). Embora a área apresente vegetação arbórea de grande porte, não há gramados e jardins; é uma área densamente construída, com ruas pavimentadas e tráfego significativo de veículos devido à proximidade com o centro da cidade. 
Caracterização do clima urbano em Teodoro Sampaio/SP: Uma introdução

Simone Scatolon Menotti Viana, Margarete Cristiane de Costa Trindade Amorim

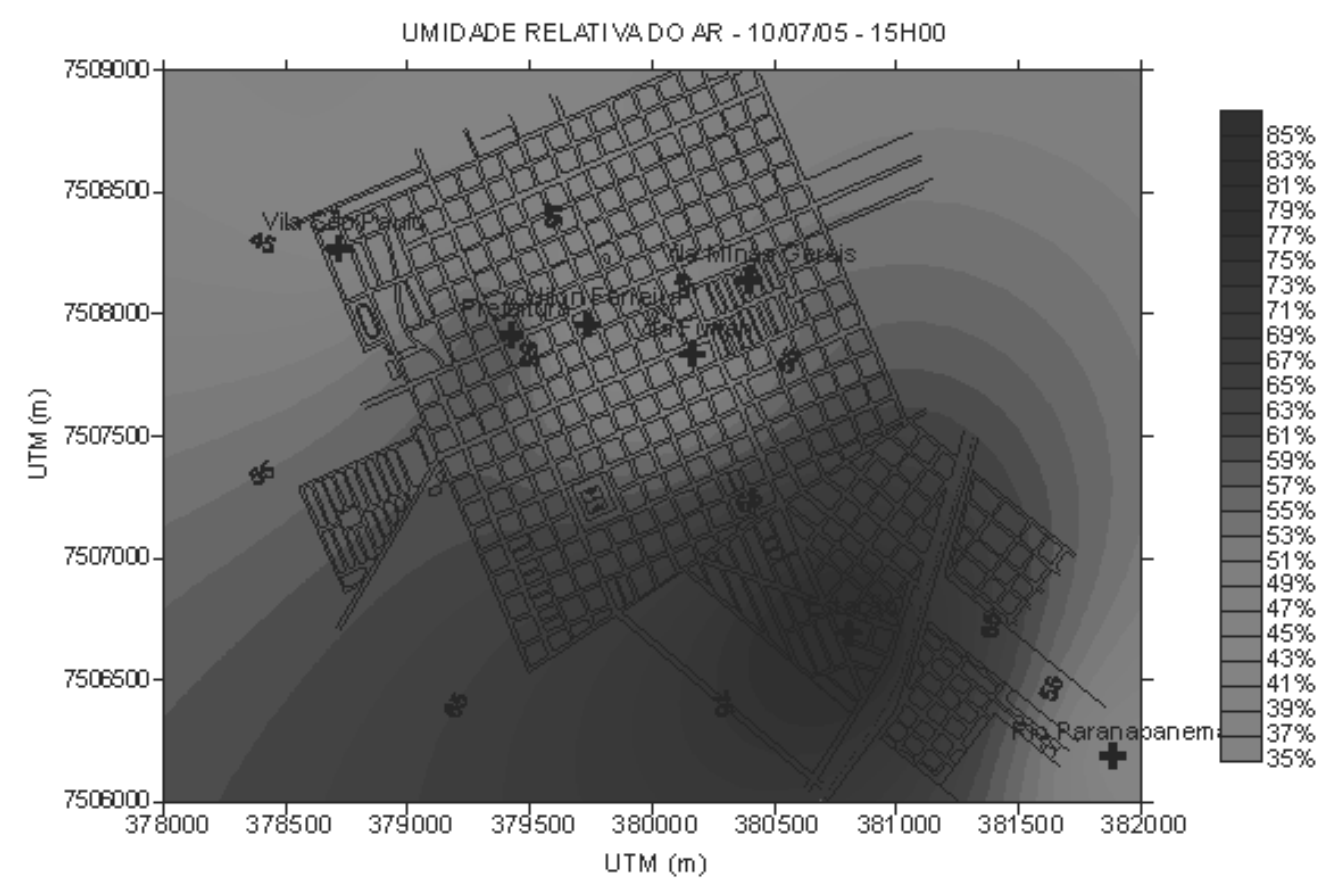

Figura 14 - Isoígras às $15 \mathrm{~h}$ - padrão predominante no inverno

As ilhas secas e de umidade que se formaram às $15 \mathrm{~h}$, no inverno, demonstram a importância da vegetação rasteira como atenuantes da temperatura e responsáveis pela elevação na umidade relativa intraurbana em Teodoro Sampaio, até mesmo em áreas mais edificadas como na área central da cidade (Prefeitura). Nas áreas com gramados e jardins (Estação) a umidade foi mais elevada do que nas áreas que apresentavam apenas vegetação arbórea e o solo todo coberto e impermeabilizado pelo concreto das calçadas e asfalto nas ruas (Odilon Ferreira).

Às 21h, no verão, em muitos dias, houve homogeneização nos valores de temperatura entre os pontos e diminuição da magnitude da ilha de calor, conseqüência da precipitação dos fins de tarde ou mesmo durante o horário da coleta dos dados. No inverno, sem a presença da precipitação, não houve homogeneização da temperatura e as áreas urbanas continuaram devolvendo calor para a atmosfera e as áreas menos urbanizadas juntamente com o ponto rural apresentaram diminuição na temperatura.

Às $21 \mathrm{~h}$, durante o verão, a ilha de calor se formou no ponto Odilon Ferreira e, em alguns dias, em específico na Vila São Paulo. A maior magnitude foi observada na Vila São Paulo e pode ser classificada como de forte intensidade. No inverno, a ilha de calor não se configurou em uma área e sim em um eixo. A ilha de calor abrangeu os três pontos, Vila São Paulo, Prefeitura e Vila Furlan. A magnitude observada pode ser classificada como sendo de moderada intensidade. (Tabela 4)

Tabela 4 - Magnitudes máximas da ilha de calor às $21 \mathrm{~h}$

\begin{tabular}{cccccc}
\hline & VERÃO & & \multicolumn{3}{c}{ INVERNO } \\
\hline Dia & Magnitude & $\begin{array}{c}\text { Sistema } \\
\text { atmosférico }\end{array}$ & Dia & Magnitude & $\begin{array}{c}\text { Sistema } \\
\text { atmosférico }\end{array}$ \\
\hline $17 /$ jan & $4^{\circ} \mathrm{C}$ & Frente Fria & $10 /$ jul & $3,5^{\circ} \mathrm{C}$ & $\mathrm{MPV}$ \\
\hline
\end{tabular}


Caracterização do clima urbano em Teodoro Sampaio/SP: Uma introdução Simone Scatolon Menotti Viana, Margarete Cristiane de Costa Trindade Amorim

A ilha de calor formada durante o verão, às 21h, nas imediações da Rua Odilon Ferreira (Figura 15) evidenciou a capacidade da conservação de energia depois do pôr-do-sol nas áreas mais edificadas, principalmente no centro da cidade. As propriedades térmicas do meio urbano, com capacidade calorífica e condutividade dos materiais de construção, possibilitaram uma grande estocagem de energia que, liberadas para a atmosfera urbana sob a forma de calor sensível, impedem seu rápido resfriamento noturno. Associado a este fator está o calor antropogênico, gerado pelo intenso tráfego de veículos (caminhões) na área central, principalmente à noite, assim maximizando o calor que está sendo devolvido pelos materiais utilizados nas construções (concreto e asfalto) para a atmosfera urbana.
No caso da Vila São Paulo (Figura 15), a formação da ilha de calor está vinculada ao funcionamento de uma cerâmica, que nos dias em que a ilha de delineou estava com suas fornalhas acessas, desde o entardecer.

Às $21 \mathrm{~h}$, as ilhas de frescor formaram-se na Vila São Paulo e no Bairro da Estação com mais persistência. Na Vila São Paulo o que auxiliou na formação da ilha de frescor foi a ocupação do solo, vegetação arbórea e rasteira em quantidade significativa associada ao sistema atmosférico atuante que favoreceu o aumento da temperatura nas demais áreas da cidade. Na Estação, a ocupação do solo foi a principal responsável pela ilha de frescor.

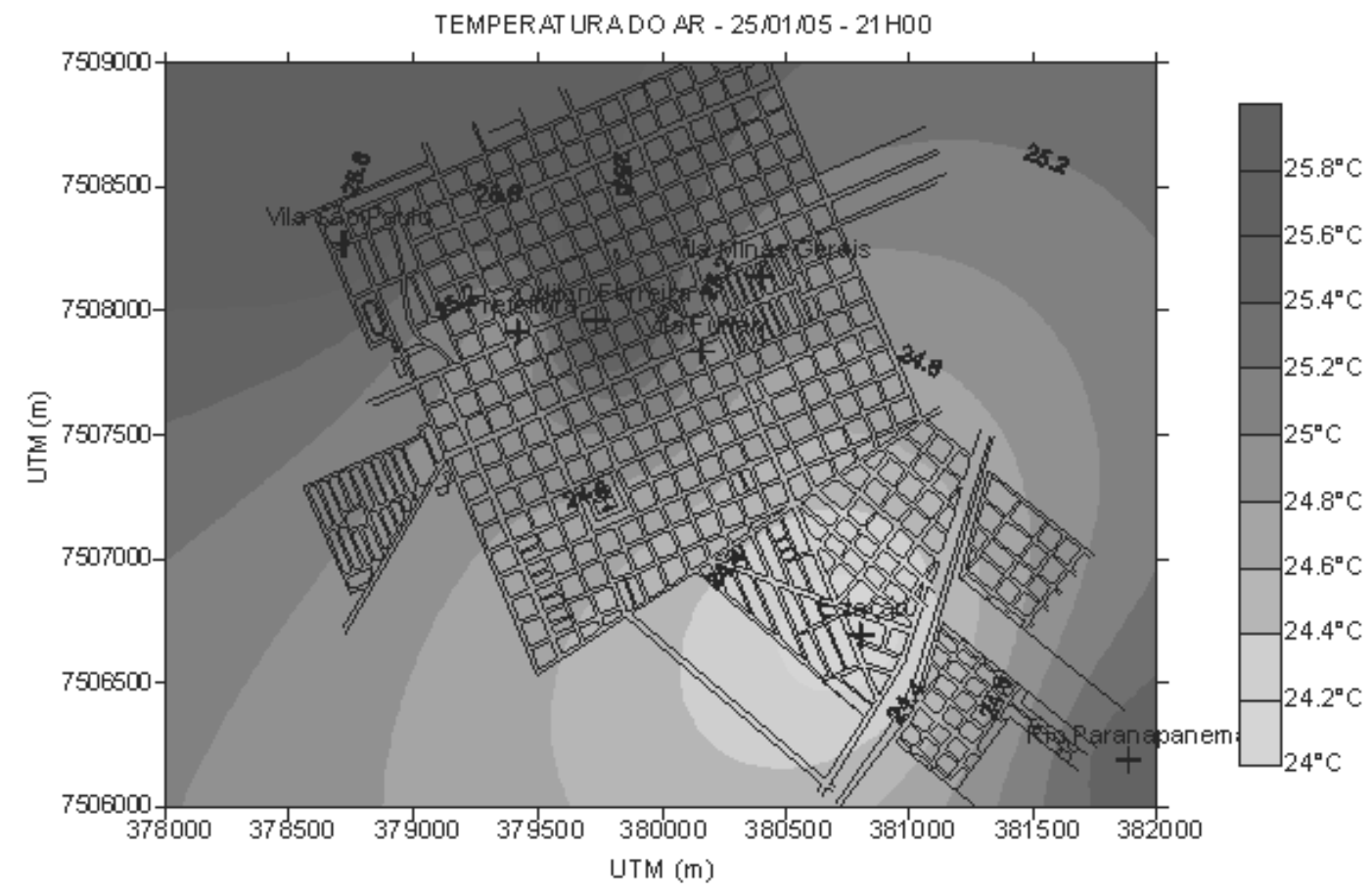

Figura 15 - Isotermas às $21 \mathrm{~h}$ - padrão predominante no verão 
Caracterização do clima urbano em Teodoro Sampaio/SP: Uma introdução Simone Scatolon Menotti Viana, Margarete Cristiane de Costa Trindade Amorim

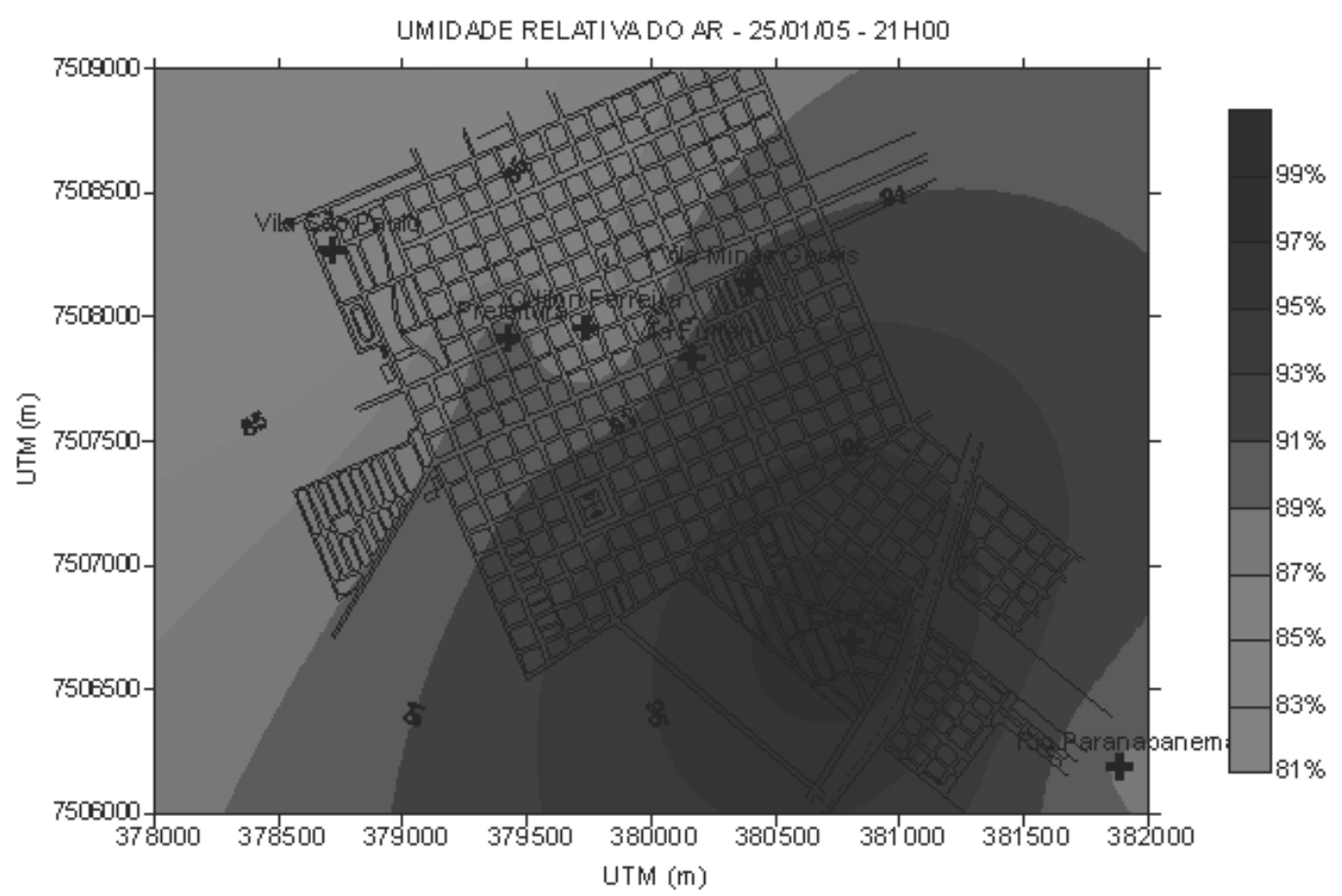

Figura 16 - Isoígras às $21 \mathrm{~h}$ - padrão predominante no verão

As ilhas de umidade se formaram nas proximidades do Rio Paranapanema e no Bairro da Estação. E as ilhas secas se formaram nas imediações da Rua Odilon Ferreira e em dias específicos na Vila São Paulo associada à ilha de calor. (Figura 16)

No inverno, as ilhas se delinearam na Prefeitura e Vila Furlan; em muitos dias, ambos os pontos apresentaram os mesmos valores de temperatura. As ilhas de calor que se formaram durante a noite permaneceram até o início da manhã.

A ilha de calor formada na área central da cidade (Prefeitura) evidencia a capacidade dos materiais típicos do meio urbano (concreto e asfalto) de armazenarem e devolverem radiação por mais tempo.
A grande evidência nesse horário, com certeza, é a formação da ilha de calor na Vila Furlan, local com menor densidade de construções, ruas sem pavimentação e vegetação arbórea e rasteira (gramados e jardins), demonstrando que durante o inverno a vegetação rasteira estando seca e sem umidade não contribuiu para a diminuição da ilha de calor e configuração das ilhas de frescor e umidade. A ilha de frescor se formou na Estação, como no verão e nos demais horários. (Figura 17)

As ilhas de umidade estiveram mais presentes na Estação (Figura 18) e no Rio Paranapanema com pequeno aparecimento durante as perturbações frontais que elevaram os índices de nebulosidade. As ilhas secas se formaram na Vila São Paulo e Odilon Ferreira e as ilhas de calor se delinearam na Prefeitura e Vila Furlan. 
Caracterização do clima urbano em Teodoro Sampaio/SP: Uma introdução Simone Scatolon Menotti Viana, Margarete Cristiane de Costa Trindade Amorim

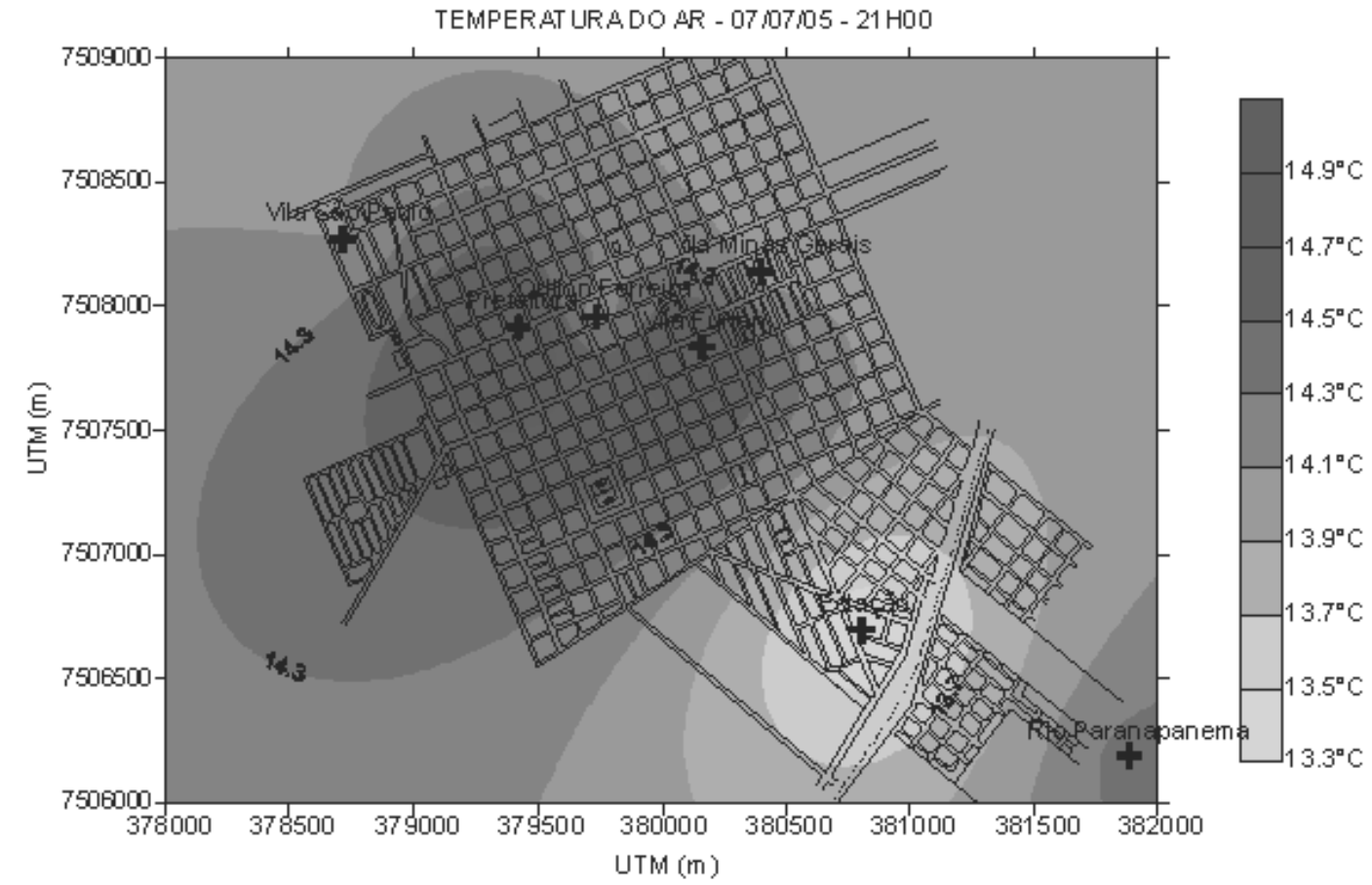

Figura 17 - Isotermas às $21 \mathrm{~h}$ - padrão representativo no inverno

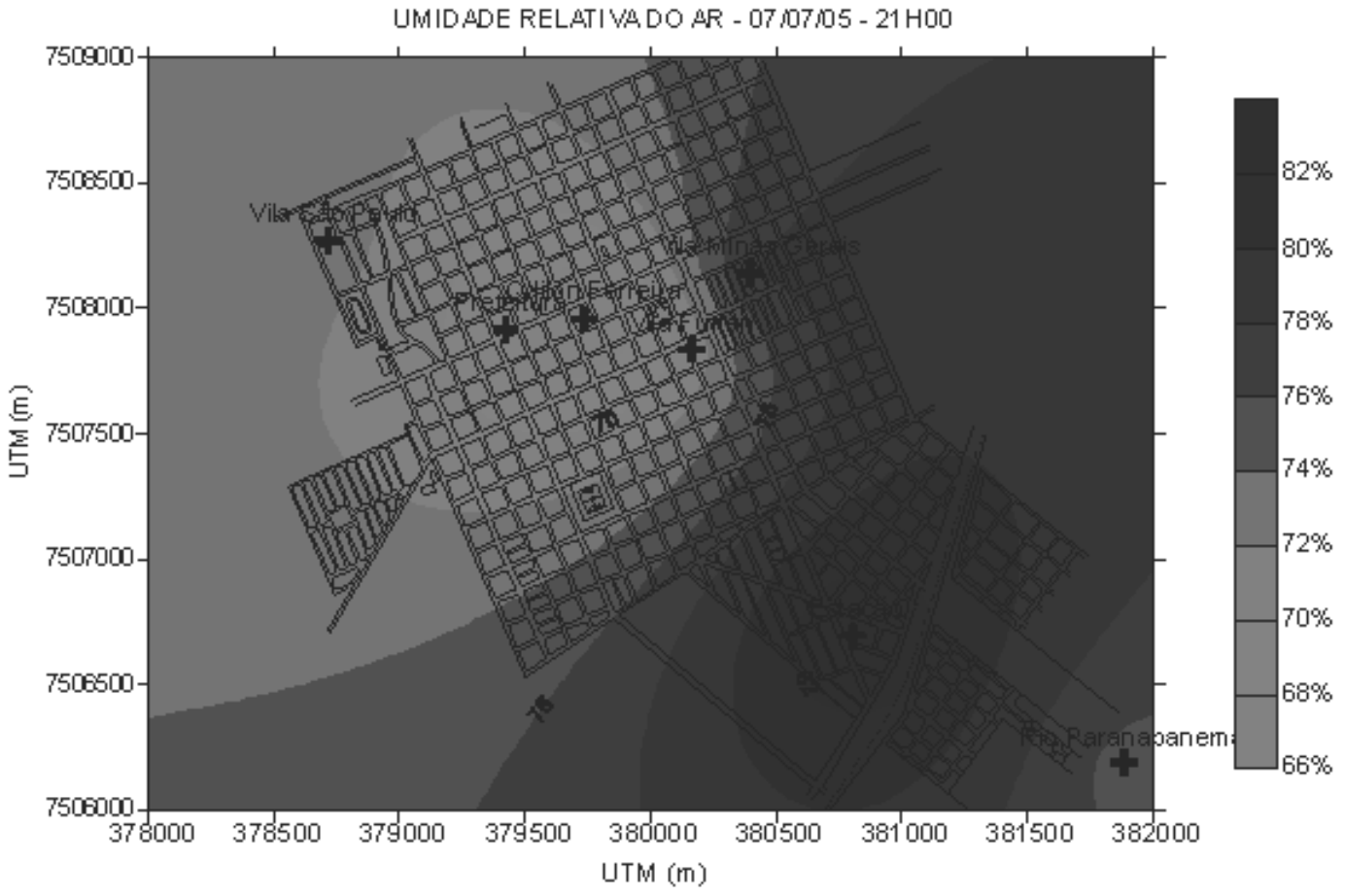

Figura 18 - Isoígras às $21 \mathrm{~h}$ - padrão predominante no inverno 
Caracterização do clima urbano em Teodoro Sampaio/SP: Uma introdução

Simone Scatolon Menotti Viana, Margarete Cristiane de Costa Trindade Amorim

Ao final, a Tabela 5 oferece uma síntese das magnitudes das ilhas de calor encontradas em Teodoro
Sampaio para cada estação estudada e em qual bairro se manifestaram.

Tabela 5 - Síntese das magnitudes das ilhas de calor observadas em Teodoro Sampaio.

\begin{tabular}{c|c|c|c|c}
\hline & \multicolumn{2}{|c|}{ VER̃̃O } & \multicolumn{2}{c}{ INVERNO } \\
\hline Horário & Magnitude/Dia & Localização & Magnitude/Dia & Localização \\
\hline $7 \mathrm{~h}$ & $2,2^{\circ} \mathrm{C}(26 / 01)$ & Odilon Ferreira & $3,8^{\circ} \mathrm{C}(10 / 07)$ & Prefeitura \\
\hline $9 \mathrm{~h}$ & $3,9^{\circ} \mathrm{C}(21 / 01)$ & Vila Minas Gerais & $2,9^{\circ} \mathrm{C}(09 / 07)$ & Estação \\
\hline $15 \mathrm{~h}$ & $5,4^{\circ} \mathrm{C}(18 / 01)$ & Rio Paranapanema & $4{ }^{\circ} \mathrm{C}(06 / 07)$ & Vila Minas Gerais \\
\hline $21 \mathrm{~h}$ & $4{ }^{\circ} \mathrm{C}(17 / 01)$ & Vila São Paulo & $3,5^{\circ} \mathrm{C}(10 / 07)$ & Prefeitura \\
\hline
\end{tabular}

No geral, com relação à direção e velocidade do vento cabe considerar que, estiveram diretamente condicionadas aos sistemas atmosféricos atuantes. No verão, foram mais fortes, principalmente no período da manhã e, no inverno, no período da tarde. Tanto no verão como no inverno durante a noite foram observadas situações de calmaria ou de leve brisa, principalmente nas proximidades do Rio Paranapanema.

O entorno rural da cidade caracteriza-se por pastagens que deixam o solo coberto durante todas as estações do ano. Este fato não propicia diferenças térmicas resultantes de solos nus ou com presença de alguma cultura, como se observou em outras pesquisas, como, por exemplo, Mendonça (1994).

Assim, os sistemas atmosféricos serviram como definidor do ritmo diário dos elementos climáticos e com relação às diferenças térmicas e higrométricas encontradas foram os responsáveis pela maximização, diminuição ou desaparecimento total delas.

\section{CONSIDERAÇÕES FINAIS}

Teodoro Sampaio, cidade de pequeno porte, com população urbana de aproximadamente 16.000 habitantes já apresenta características peculiares quanto ao uso e ocupação do solo, fruto da sua ocupação inicial e do seu desenvolvimento posterior.
Este estudo priorizou o entendimento das condições climáticas geradas em uma cidade de pequeno porte, mas que já apresenta especificidades quanto ao uso e ocupação do solo. Para tal foram utilizadas as proposições teórico-metodológicas propostas por Monteiro em 1976 e 1990. Assim, a cidade foi estudada a partir do Sistema Clima Urbano, que trata o clima da cidade com base numa perspectiva geográfica, a partir de uma visão integrada entre o homem, a natureza e a cidade sob uma mesma atmosfera.

Com base nessa proposição, foi realizada a caracterização climática para a cidade de Teodoro Sampaio. A caracterização climática foi estabelecida a partir da análise do clima regional com base na dinâmica atmosférica e na análise do clima local realizada com as observações-mensurações de dados de temperatura do ar, umidade relativa do ar e direção e velocidade do vento. Na caracterização climática regional e local foram consideradas as influências do relevo, da hidrografia e do uso e ocupação do solo, nas modificações do clima urbano de Teodoro Sampaio.

As ilhas de calor e frescor, bem como as ilhas úmidas e secas, apresentaram magnitudes e comportamento diferenciados, de acordo com o horário e a estação do ano, o uso e a ocupação do solo e o sistema atmosférico atuantes.

No verão, as magnitudes das ilhas de calor coincidem com o horário de maior devolução de 
radiação terrestre para a atmosfera: começam a se delinear às $9 \mathrm{~h}$ e se definem completamente às $15 \mathrm{~h}$. Nos horários de $7 \mathrm{~h}$ e $21 \mathrm{~h}$, as ilhas de calor foram observadas nas áreas densamente construídas, com pouca vegetação (Prefeitura) e na área densamente construída com vegetação arbórea de grande porte (Odilon Ferreira).

No inverno, as maiores magnitudes também foram observadas às $15 \mathrm{~h}$, embora os valores apresentados durante a manhã (7h) e noite (21h) tenham sido muito similares ao valor encontrado às 15h. No inverno (7h), a ilha de calor formada em Odilon Ferreira desaparece, permanecendo apenas a configurada na Prefeitura.

No verão, os fatores que favoreceram as diferenças térmicas e higrométricas foram: a precipitação abundante, a densidade de construções e os índices de vegetação arbórea e rasteira. A chuva proporcionou dois padrões de distribuição da temperatura e umidade e o que determinou o ritmo diário desses elementos. A densidade de construções favoreceu na determinação das magnitudes térmicas e higrométricas entre os pontos. A vegetação rasteira (gramados e jardins) associada ao orvalho e à chuva foi um fator decisivo no comportamento térmico e higrométrico, principalmente, durante a manhã e fins de tarde.

No inverno, os fatores que influenciaram na distribuição térmica e higrométrica foram: densidade de construções, os índices de vegetação arbórea (grande porte) e a baixa velocidade do vento associada à pouca nebulosidade. Cabe dizer que, durante o inverno, não houve precipitação e a vegetação rasteira não apresentou a mesma contribuição na diminuição térmica e elevação da umidade relativa, como no verão. E ainda, as formações das ilhas de calor tiveram contribuição mais evidente dos sistemas atmosféricos que proporcionaram céu limpo com baixa velocidade do vento.

O estudo demonstrou que a inércia calórica dos materiais constituintes do meio urbano (asfalto, concreto), a vegetação (arbórea e rasteira), o calor antropogênico, os sistemas atmosféricos atuantes foram fatores decisivos para a configuração das diferenças térmica e higrométrica intra-urbana em Teodoro Sampaio. Assim, evidenciou-se que as condições climáticas intra-urbanas geradas na cidade estão ligadas diretamente à heterogeneidade da ocupação do solo e das funcionalidades urbanas, o que acabou gerando para a cidade ilhas de calor e de frescor, bem como as ilhas úmidas e secas.

\section{REFERÊNCIAS BIBLIOGRÁFICAS}

BARRIOS, N.A.Z., SANT'ANNA NETO, J.L. A circulação atmosférica no extremo oeste paulista. Boletim Climatológico, Presidente Prudente, v.1, n.1, p.8-9, março 1996.

CLIMANÁLISE. Boletim de monitoramento e análise climática, v.20, n.01, jan.2005. Disponível em:<www. http://tucupi.cptec.inpe.br/products/ climanalise.

CLIMANÁLISE. Boletim de monitoramento e análise climática, v.20, n.07, jul.2005. Disponível em:<www. http://tucupi.cptec.inpe.br/products/ climanalise.

FARIA, H. H. et al. O clima e sua influência no Parque Estadual do Morro do Diabo, Teodoro Sampaio-SP, Brasil. In: IV SEMINÁRIO LATINOAMERICANO DE GEOGRAFIA FÍSICA, 2006, Maringá. CD-Rom. Maringá: Universidade Estadual de Maringá, 2006. v. 1, p. 1-13.

MENDONÇA, F.A. O clima e o planejamento urbano de cidades de porte médio e pequeno. Proposição metodológica para estudo e sua aplicação à cidade de Londrina / PR. São Paulo, 1994. Tese (Doutorado em Geografia Física) Faculdade de Filosofia, Letras e Ciências Humanas, Universidade de São Paulo.

MONTEIRO, C.A de F. Teoria e clima urbano. 25. São Paulo: IGEOG/USP, 1976. 181p. (Série teses e Monografias, 25). 
Caracterização do clima urbano em Teodoro Sampaio/SP: Uma introdução

Simone Scatolon Menotti Viana, Margarete Cristiane de Costa Trindade Amorim

MONTEIRO, C.A de F. Por um suporte teórico e prático para estimular estudos geográficos do clima urbano no Brasil. Geosul, Florianópolis,v.5, n.9, p.719, 1990.a

MONTEIRO, C.A de F. Adentrar a cidade para tomarlhe a temperatura. Geosul, Florianópolis, v.5, n.9, p. 61-79,1990.b

MONTEIRO, C.A de F. A cidade como processo derivados ambiental e estrutura geradora de um "Clima Urbano". Geosul, Florianópolis, v.5, n.9, p. 80-114, 1990.c

SEZERINO, M. L., MONTEIRO, C. A. F. O campo térmico na cidade de Florianópolis: primeiros experimentos. Geosul, Florianópolis, v.5, n.9, p. 2060, 1990. 